Document downloaded from:

http://hdl.handle.net/10251/62344

This paper must be cited as:

Hervás Oliver, JL.; Albors Garrigós, J.; Miguel Molina, MBD.; Hidalgo, A. (2012). The role of a firm's absorptive capacity and the technology transfer process in clusters: How effective are technology centres in low-tech clusters?. Entrepreneurship and Regional Development. 24(7-8):523-559. doi:10.1080/08985626.2012.710256

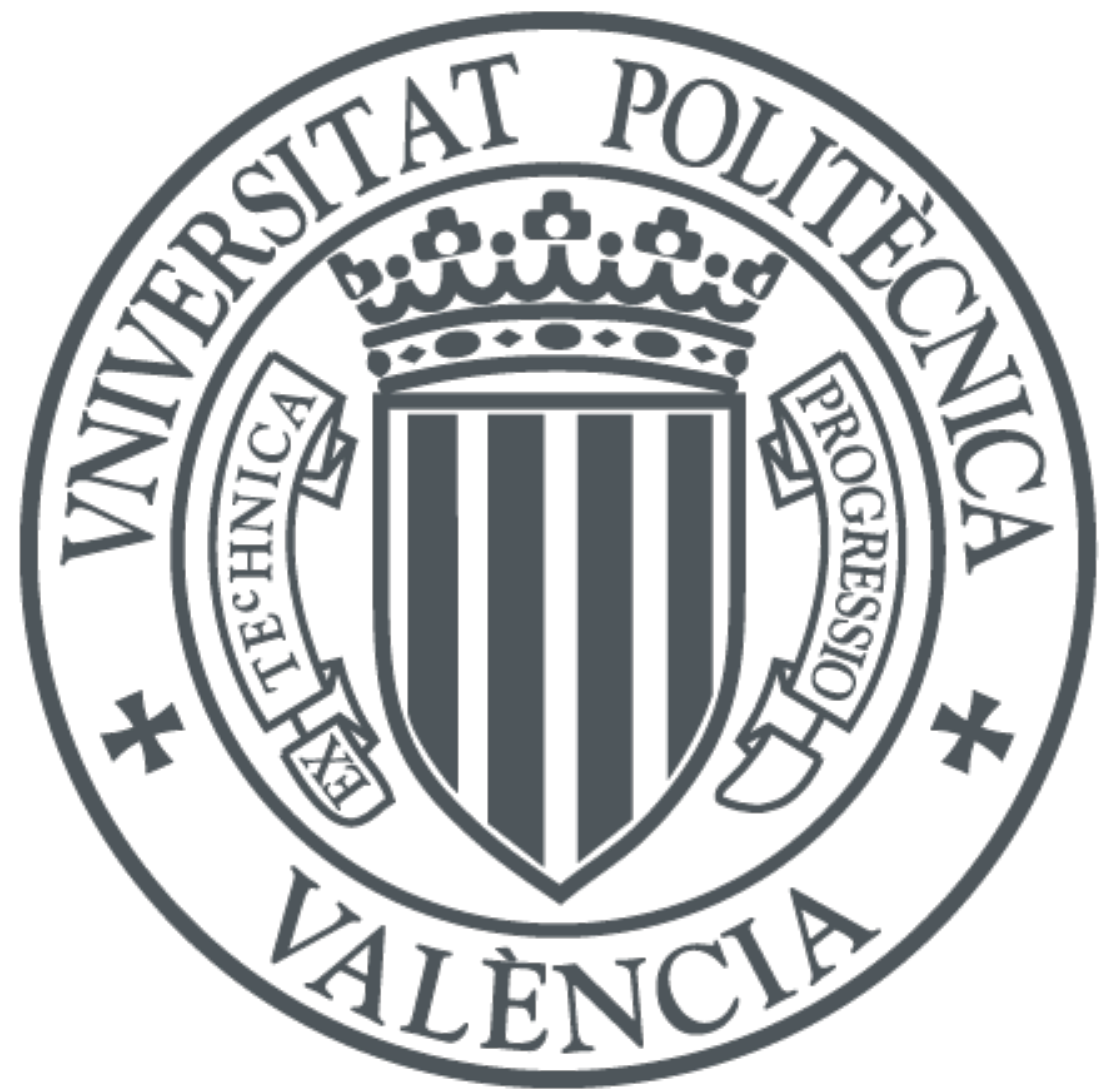

The final publication is available at

http://dx.doi.org/10.1080/08985626.2012.710256

Copyright Taylor \& Francis (Routledge): SSH Titles

Additional Information 


\title{
The role of a firm's absorptive capacity and the technology transfer process in clusters: How effective are technology centres in low-tech clusters?
}

\author{
Jose-Luis Hervas-Oliver, Jose Albors-Garrigos \\ Blanca de-Miguel and Antonio Hidalgo
}

\begin{abstract}
This paper analyses how the internal resources of small- and medium-sized enterprises determine access (learning processes) to technology centres (TCs) or industrial research institutes (innovation infrastructure) in traditional low-tech clusters. These interactions basically represent traded (market-based) transactions, which constitute important sources of knowledge in clusters. The paper addresses the role of TCs in low-tech clusters, and uses semi-structured interviews with 80 firms in a manufacturing cluster. The results point out that producer-user interactions are the most frequent; thus, the higher the sector knowledge-intensive base, the more likely the utilization of the available research infrastructure becomes. Conversely, the sectors with less knowledge-intensive structures, i.e. less absorptive capacity (AC), present weak linkages to TCs, as they frequently prefer to interact with suppliers, who act as transceivers of knowledge. Therefore, not all the firms in a cluster can fully exploit the available research infrastructure, and their $\mathrm{AC}$ moderates this engagement. In addition, the existence of TCs is not sufficient since the active role of a firm's search strategies to undertake interactions and conduct openness to available sources of knowledge is also needed. The study has implications for policymakers and academia.
\end{abstract}

Keywords: clusters; absorptive capacity; technology centres; industrial research institutes; SMEs

\section{Introduction}

The literature on clusters points out that un-traded knowledge externalities (KS) take place mainly through local labour mobility, spin-offs and from the interactions between the staff of different local firms (with suppliers, customers, competitors and so forth; Saxenian 1994). However, the traded (transactions) flows of knowledge in clusters, which are market-based, have received less attention from scholars (Malmberg and Power 2005; Antonelli, Patrucco, and Quatraro 2011). This paper explores this gap regarding the complexity of innovation in clusters and addresses flows of knowledge other than the un-traded ones. In this study, we adopt the idea of Scitovsky (1954) in defining traded transactions as those occurring in a voluntary and pecuniary way. In this vein, one important provider of traded (sometimes confused 
with un-traded interactions) flows of knowledge is the industrial research institutes (IRIs) or technology centres (TCs). ${ }^{1}$ TCs are defined as technology institutes which provide services to firms in order to complement their knowledge, offering services such as training, information, intermediation, technological assessment and consulting, or R\&D and innovation projects. As suggested in the study by GarcíaQuevedo and Mas-Verdú $(2008,139)$, the services offered by TCs can be classified according to the functions developed: (i) activities related to the diffusion of knowledge (training, information, demonstration); (ii) activities encouraging interaction between agents in the system, especially firms, promoting cooperation or improving information transactions based on the knowledge and experience of the agents (intermediation) and (iii) activities of a more individual kind, consisting of the provision of specific services to specific firms (tailored training, technological assessment and consulting). A second classification addresses the different services offered by TCs according to the stage of the production process (COTEC 2003), such as those concerned with the generation and acquisition of knowledge and technology ( $R \& D$ projects, producing prototypes, advice on the purchase of technological equipment, training, etc.), the preparation for production (testing, product certification, access to laboratory facilities or pilot engineering installations) or even providing information to effectively compete in new markets and support in the commercialization of products. For example, Arnold et al. $(2007,57)$ state that the IRECO Swedish institutes perform two different types of activities. Firstly, those associated with product and process development, mainly based on applied research, advanced engineering, design and development and applications engineering, and secondly, activities ranging from technical services, such as education and training to prototype production, of which the most frequent is measurement, testing and certification. TCs 'typically use a three step innovation model: building capabilities, using core funding and other aspects such as co-operations with universities; extending these in pre-competitive work with industry; and finally using them to deliver services as the technologies mature' (57).

According to Mas-Verdú (2007,10-11) TCs are among the suppliers of knowledge-intensive services. These services are determined by three variables: users' demands, which are a function of the economic and commercial structure of the environment; the strategic options chosen by the governing boards of the centres and, if appropriate, the guidelines decided by public administrations that may eventually contribute to financing these centres. In addition, the activities can be classified as those related to day-to-day operations and others that have long-term goals. The former are represented by the quality control of raw materials and other technical consulting services as quality or environmental certifications. The latter refer to R\&D and innovation support projects (new products, new processes of production, and new methodologies, etc.).

TCs are relevant sources of knowledge in the literature on clusters, termed as scientific institutes (Porter 1990), public and private research institutes (Asheim and Coenen 2005; Chaminade and Vang 2008), regional public research organizations (PROs; Belussi, Sammarra, and Sedita 2010), research institutes (Marklund et al. 2004), TCs (Parrilli, Aranguren, and Larrea 2010) or research centres (Clark 2010). Usually, TCs are located in the theoretical sphere of regional systems of innovation (RIS) as key institutes or advance technology infrastructures, which make up the innovation systems in regions and clusters (Cooke, Uranga, and Etxebarria 1997; 
Hervas-Oliver and Albors-Garrigos 2007). As a matter of fact, the Danish Technology Institute (DTI) or the ERVET in the Emilia-Romagna region (Italy) (Ervet 1997) are examples of TCs for nurturing knowledge in small- and mediumsized enterprises (SMEs). Likewise, the network research infrastructure in BadenWürttemberg (Fraunhofer Institutes, Steinbeis Foundation or Industrial Research Centres, etc. $)^{2}$ is designed to serve SMEs, as well as the IRECO research institutes of the Swedish National System of Innovation (Arnold et al. 2007). Nevertheless, "the literature on research institutes is small and sheds only a little light on what they do in practice, while much of the debate seems to have been conducted more on the basis of assumption than on hard evidence' (11). Clusters, as unit of analysis in this case, are important due to the fact that the innovation process is interactive and localized, thus proximity and interactions are major components of clusters (Lundvall and Johnson 1994; Asheim and Isaksen 2000). Our study contributes to filling this research gap by analysing one TC, its activities and the services demanded by co-located firms in a cluster.

The literature on clusters or industrial districts (Hervas-Oliver and AlborsGarrigos 2007, 2008; Li and Geng 2011) has always emphasized the role of local organizations as important assets in clusters (Maillat 1989; Wolfe and Gertler 2004).

Among the supporting organizations available in clusters, such as trade and professional associations, vocational training centres and universities, TCs are important due to their role in knowledge creation and diffusion and their direct focus on co-located firms (Asheim and Coenen 2005; Arnold et al. 2007; Hervas-Oliver and Albors-Garrigos 2007).

It should be mentioned that when addressing clusters in traditional industries, most cases are based on the services provided by the TCs (Asheim and Coenen 2005; Arnold et al. 2007; Hervas-Oliver and Albors-Garrigos 2007; Mas-Verdú 2007; Parrilli, Aranguren, and Larrea 2010). The TCs explore knowledge opportunities and diffuse new technology and applications within the clusters (Galaskiewicz 1985), acting as knowledge intermediaries in a process of an institutional thickening that enhances the competitiveness and performance of the co-located firms (Velluzzi 2010).

TCs are, by definition, different from universities and rather act as complements, and not substitutes (Arnold et al. 2007, 7). TCs are mainly aimed at collaboration and transfer knowledge to industry as part of their core mission, while universities are primarily motivated to collaborate with industry due to the need to raise additional resources required to fund research and other university activities (Cohen et al. 1998). There is no evidence to support the idea that universities can substitute the role played by the institutes. This idea is corroborated in other studies which propose that the role of the universities in promoting interactions between co-located agents in certain regions tends to be low, and universities are recognized as weak knowledge transceivers (Cooke 2005, 1131; Arnold et al. 2007). TCs are (Jensen and Tragardh 2004; Gunasekara 2006) a different type of research infrastructure to complement the day-to-day innovation activity of the firm, following the Pisa model (OECD 2001) in which they help to 'avoid the sunk costs, inertia and vested interests of traditional "bricks and mortar" academe' (Cooke 2005, 1131). TCs are created in order to provide services to foster innovation, responding to demand by specific branches of industry that are fragmented and dominated by small companies with limited research resources (as in the Swedish case, Arnold et al. 2007) or in order to 
provide services not provided by the university due to their 'applied' character (as in the case of the Valencia region (VR), see Mas-Verdú 2007). In addition, TCs are also created to regionalize the policy-making in a country (as in the case of the Baden-Württemberg region, see Mas-Verdú 2007).

The diversities of TCs observed in each country (ERVET in Emilia-Romagna, DTI in Denmark, the IRECO centres in Sweden or the Redit network of the VR) are funded in different ways, including public generic support for the financing of infrastructures, financing for specific projects through public (regional, national or European) announcements of aid for which centres compete with other agents in the innovation system, and financing through fees and prices for services rendered (Mas-Verdú 2007, 19). The importance of these forms of financing varies depending of the type of the TC and their mission.

According to Mas-Verdú, Baviera-Puig, and Martinez-Gomez (2009), the role of TCs is understood when they are systemized together with the firms which are colocated and are part of the innovation system in the territory. In order to understand this innovation system at the cluster-level, we refer to Parrilli, Aranguren, and Larrea's (2010) distinction of the concepts of innovation structures and learning processes as a means to highlight the 'innovation gap' that often exists between the two. The term innovation structures refers to the institutions devoted to creating knowledge and innovations, such as TCs, universities or other support organizations (vocational training centres, trade associations, etc.). In some studies, these institutes and their activities are intended to build regional capacities (Cooke and Leydesdorff 2006) to act as knowledge brokers in RIS (Kauffeld-Monz and Fritsch 2010) or to serve as drivers of the 'institutional thickening' process that enhances the competitiveness and performance of the co-located industry (Velluzzi 2010). Thus, the TCs are central spaces for scientific production and for technology-led regional economic development (Clark 2010). In this chain of thought, innovation structures are well described in Mas-Verdú and Ribeiro (2008), as intermediate organizations and knowledge-intensive services (Muller and Zenker 2001; Benneworth and Dawley 2004; Tura and Harmaakorpi 2005; Mas-Verdú 2007). These types of services serve a dual purpose on a regional scale: (i) they enable interaction among the actors and components of each region, and (ii) they promote the connection between the firms in the region via networks of a broader nature, both functionally and territorially speaking. In the case of smaller firms (Chiarvesio, di Maria, and Micelli 2004), such integration into external networks, principally carried out by service firms, can be of particular importance.

Existing empirical evidence on TCs in clusters is inconclusive and lacks integration. PROs or supporting organizations are almost absent from the communities or networks in clusters where knowledge is exchanged (Lissoni 2001), a fact which is confirmed in other research works (Kalantaridis and Pheby 1999; Vickers and North 2000; Kaufmann and Tödtling 2002) which provided evidence to suggest that the links between TCs and SMEs are fairly weak, or that SMEs hardly interact with TCs (Hassink 1997; Landabaso 2000; Bosco 2007; Olazaran, Albizu, and Otero 2009). Parrilli, Aranguren, and Larrea (2010, 365) analyse the case of an RTO (CIDEMCO) in a low-tech furniture cluster in the Basque Country and showed that many SMEs did not consider the role of the CIDEMCO's R\&D activities as a key driver of their competitiveness, as their innovation needs are more focused on design and marketing. Therefore, there is little evidence on TCs and their role in low 
and medium-low tech clusters. Despite the fact that the cluster literature has claimed that TCs have a positive effect on clusters (Asheim and Coenen 2005), to what extent can TCs really contribute to the promotion of innovation in clusters? How effective are they in low- and medium-tech (LMT) clusters formed by SMEs? This paper attempts to understand what types of firms make use of these TCs and which factors moderate access to these tech infrastructures, focusing on SMEs in low-tech clusters SMEs (Bennett 1998; Rolfo and Calabrese 2003; Siu, Fang, and Lin 2004). In addition, our paper covers the role of TCs in transferring knowledge, providing services and promoting innovation.

Thus far, the debate has focused mainly on the innovation infrastructure in clusters. However, as claimed by some scholars, the geography of innovation linkages, i.e., the learning mechanism, in innovation systems is still a debated issue (Belussi, Sammarra, and Sedita 2008). This paper also addresses the learning process based on interactions, which permits economic agents to appropriate the knowledge and the innovations within an innovation system (in the terms of Lundvall 1992 and Cooke 2001). The concept of learning processes could vary within a cluster with respect to certain characteristics of the business such as size and organizational structure (Gann and Salter 2000). In other words, the exploitation of advantages from external sources of knowledge will be conditioned by a firm's absorptive capacity (AC; Cohen and Levinthal 1990) from each firm located within the region (Giuliani and Bell 2005; Hervas-Oliver and Albors-Garrigos 2009; Jones, Macpherson, and Thorpe 2010; Camuffo and Grandinetti 2011; Valdaliso et al. 2011). Some authors claim that state/regional governments and their agencies should promote institutional learning (Lundvall 1992; Asheim and Coenen 2006). However, as pointed out by Parrilli, Aranguren, and Larrea (2010, 358) '... [TCs] are not sufficient to spur innovation; the simple juxtaposition of R\&D centres, labs, universities or venture capitalists may not result in innovation if they do not have effective interaction for generating valuable learning processes with the production system'. This assumption is linked to the fact that several studies have claimed the idea that co-location is not sufficient (Camagni 1991; Boschma 2005), and the firm's characteristics do matter (Giuliani 2007; Hervas-Oliver and Albors-Garrigos 2009) in order to tap into the external resources available in clusters. ${ }^{3}$ In fact, in recent years, a significant number of contributions have highlighted that the extent to which a firm will be able to benefit from collaborative networks is greatly dependent on its AC (Giuliani and Bell 2005; Giuliani 2007; Hervas-Oliver and Albors-Garrigos 2009). AC has been defined (Cohen and Levinthal 1990) as 'the ability of a firm to recognize the value of new external information, assimilate it and apply it to commercial ends' (128). This concept implies that internal capabilities are central to the firm's technological capacity and enhance its ability to assimilate and exploit external knowledge in the environments in which it maintains frequent and multiple relationships, i.e., clusters (Giuliani 2007; Hervas-Oliver and Albors-Garrigos 2009).

In fact, certain evidence has contradicted some literature that considers the influence of territory on firms (Lawson 1999; Maskell and Malmberg 1999), assuming that all firms can effectively access and exploit the external resources that are available within the territory. Barge-Gil and Modrego-Rico (2008) state that the creation of new knowledge is more efficient in TCs themselves than in the process of transferring it to firms, especially to SMEs. As a matter of fact, the weak linkages between SMEs and TCs can be explained by the fact that, in industrial districts, 
SMEs usually interact with suppliers or customers who can support the incremental innovation process mainly followed in SMEs (Lissoni 2001), while TCs and universities mainly cooperate with larger companies with a higher level of technology (Hassink 1997). Therefore, the paper explains the innovation process which occurs in clusters and addresses the manner in which a firm absorbs the available knowledge from TCs, and the drivers and moderators involved in this process.

In short, the paper contributes to exploring the interrelationships between SMEs and TCs in the case of a low-tech cluster, addressing how a firm absorbs the available knowledge from the research infrastructure, and analysing to what extent TCs can really contribute to promoting innovation in clusters. It addresses how effective TCs are in traditional low-tech clusters and how TCs contribute to the creation and diffusion of knowledge in a cluster and fills this research gap by conducting an analysis of the interactions between the knowledge infrastructure (TCs) and the learning process (firms engaging in absorbing knowledge) in a cluster. There is currently a paucity of the literature that explicitly considers traded interactions in clusters.

The contributions of this paper present implications for policy-makers and clarify the distinctive role carried out by TCs in clusters, their effect on SMEs in low-tech contexts and the effective policy-making to be implemented. Specifically, the paper focuses on SMEs in a low/medium-tech ceramic tile cluster in the VR in Spain which, with Italy (Sassuolo, Emilia-Romagna), leads the European ceramic industry. The VR in Spain was selected because this is where the highest proportion of clusters in Spain is concentrated (Boix 2009) and it is the region that also hosts the most active TCs (Mas-Verdú 2003). The paper uses non-R\&D variables to properly depict the low-tech context of the SMEs addressed.

The paper is organized as follows: Section 2 explains the theory, addressing the role of TCs, the co-located firms and the distinction between traded and un-traded interactions. Next, Section 3 justifies why the paper is set in the Spanish context, explaining the type of $\mathrm{TCs}$ available in the selected (Valencia) region and deconstructing the Spanish ceramic tile cluster which is explored. Section 4 describes the empirical study carried out, interpreting and discussing results, while the last section presents the conclusions, connecting them to the theory and offering implications for policymakers and academia. Future research challenges are also suggested.

\section{Theory}

\subsection{TCs and their role in clusters}

Mas-Verdú (2007) claims that the concentration of SMEs requires a supply of knowledge-intensive services through TCs as one basic policy for business development (Gorman and McCarthy 2006). Indeed, innovation is one of the key factors for the survival, growth and development of SMEs (Acs and Audretsch 1990). For this purpose, both developed knowledge in-house, and interactions aimed at accessing new knowledge are the main providers of valuable resources that enable a sustainable competitive advantage for firms. With regard to accessing external (to the firm) available knowledge in clusters, ${ }^{4}$ the literature stresses $\mathrm{KS}$ as crucial external sources of knowledge for achieving innovation (Griliches 1979; Jaffe, Trajtenberg, and Henderson 1993). Externalities or KS have been considered in 
economic literature as densely tied networks which allow and promote tacit knowledge transmission and trust (Uzzi 1996), and a paradoxical combination of cooperation and competition within the territory (Harrison 1991). The literature points out that KS take place mainly through local labour mobility, spin-offs and also from the interactions between the staff of different local firms (with suppliers, customers, competitors and so forth; Saxenian 1994) in clusters. Nevertheless, these KS represent sources of external knowledge for firms as long as the externalities are unintended transfers of knowledge flows or, using Dosi (1984) and Storper's (1995) terminology, un-traded relationships. Following this chain of thought, in cluster literature, the un-traded flows have been a central part of the theory, although it is claimed that there are also explicit and intended acts of collective learning in networks (Crevoisier 2004).

TCs are characterized by heterogeneity in relation to their mission, ownership, legal and organizational status or output (Leitner 2005). The mission of TCs is a difficult one, as they have to combine basic (push) and development (demand-pull) research (Justman and Teubal 1995, 277). In Europe, these organizations have various outputs ranging from basic research to product development or technical services and engineering (Mas-Verdú 2007). TCs are a fundamental tool for regional innovation policy and their main role is to address market failures such as appropriability barriers, a well-defined information market, innovation uncertainty and the size of the SME population (Barge-Gil and Modrego-Rico 2008) in their environment. In many countries, TCs carry a substantial weight of the investment in R\&D and their role may vary according to their national context (Aström, Eriksson, Arnold 2008). They cannot be substituted by universities since their services are completely different (Arnold et al. 2007). The objectives of technology institutes are (Barge-Gil and Modrego-Rico 2008): (1) to research and create new technological knowledge; (2) to transfer technology to their clients; (3) to act as a catalyst for interaction among agents; these objectives are quite different from those of universities, in which education and knowledge (not specifically technical) are central.

TCs contribute as key agents of their territorial innovation system or clusters, creating and diffusing knowledge and offering connectivity between innovation agents (Antonelli 1988; Tann, Platts, and Stein 2002; Cooke et al. 2007; Barge-Gil and Modrego-Rico 2008; Martínez-Gómez, Baviera Puig, and Mas-Verdú 2009) and thus they contribute to fostering innovation (Metcalfe and Miles 2000; Miles 2001). Nevertheless, the impact of local TCs on clusters is complex and depends on preconditions (Sölvell, Lindqvist, and Ketels 2003) to such an extent that there is a lack of consensus about the types of promotional policies through local organizations which effectively support clusters (Wolfe and Gertler 2004).

Despite the large number of clusters/industrial districts (IDs) analysed in the literature, there are very few cases describing how low-tech clusters are upgraded and promoted through TCs or other types of technology infrastructure. In most cases, TCs and other research infrastructures are cited as being a heavily used asset by colocated firms in clusters (Maillat 1989; Asheim and Coenen 2005). According to Lissoni (2001), the interactions between firms and local organizations in high-tech clusters are not observed or are, at least, less intense in low-tech clusters, confirming the findings of Parrilli, Aranguren, and Larrea (2010). However, the major literature addressing this phenomenon is mainly based on high-tech clusters (Dahlander and McKelvey 2005; Casper 2007; Robinson, Rip, and Mangematin 2007; Belussi, 
Sammarra, and Sedita 2008) and on links with universities. The study by Belussi, Sammarra, and Sedita (2008) on TCs and the interaction among firms in the life science industry in the Emilia-Romagna region evidenced that tech centres have a higher propensity than firms to engage in research relationships, i.e., the majority of tech centres collaborate with other tech centres. Therefore, the large majority of research evidenced scant interaction between firms and TCs (Lagendijk 2000; Landabaso 2000; Kaufmann and Wagner 2005; Tödtling and Trippl 2005), especially in clusters (Hassink 1997; Lissoni 2001), and this last author suggests that low-tech clusters offer a great opportunity to conduct important research.

\subsection{Search strategies in the learning environment: The paradox of traded versus un-traded}

The literature stresses that interactions take place with co-located firms and supporting organizations in the same regional area (Lundvall and Borras 1999). Due to their particular characteristics, SMEs are more dependent on these local/regional interactions (Asheim, Coenen, and Svensson-Henning 2003) than large firms, which are also linked to national and international networks (Coenen, Moodysson, and Asheim 2004). SMEs rely more on personal ways of transferring tacit (local) knowledge, i.e., learning via interaction (Chaminade and Vang 2008). The intensity of such interaction and the exchange of knowledge in RISs are dependent upon the firm's social capital (Coleman 1988). Access to external local knowledge by colocated firms may be easier due to the trust, mutual understanding or the use of the same language, as well as shared values that exist in the local context (Bellandi 1989; Maillat 1989; Becattini 1990; Capello and Faggian 2005). It is important to note that, within a firm's resources, the social capital asset, described by Uzzi (1996) as trust based on social relationships and continuous interactions, is a vital driver, and is far from a merely geographic distance concept, moderating the access to local knowledge and interaction (Boschma 2005; Jenkins and Tallman 2010). Nevertheless, complementing the latter, in recent years, the concept of $\mathrm{AC}$ is also considered a key dimension for absorbing knowledge in territories (Chaminade and Vang 2008).

Despite the recognition that traded interactions are intertwined with social and personal ties (Scott 1988; Maillat 1990), the literature seems to focus more on the untraded side. Some authors draw attention to the overrated significance given to knowledge spillovers (KS, hereinafter) (Breschi and Lissoni 2001; Scott 2004). To be more precise, the Breschi and Lissoni $(2001,976)$ reference to KS or externalities as a mere black box is based on the fact that most of the externalities that take place in clusters are merely pecuniary externalities that occur in clusters in a market-based transaction. Thus, information flows take place in formal and informal networks. In fact, most of the literature on clusters has not empirically proved this difference between traded and un-traded interactions. Breschi and Lissoni $(2001,999)$ propose that the considerable abuse of the KS concept does not prevent it from being an extremely important agglomeration force, but there are other flows of knowledge in clusters beyond the un-traded flows which may be classified as a different type and are also external sources of competitive advantage.

Literature on social capital confirms the overlap between traded and un-traded flows. Uzzi (1997) claims that understanding interactions implies considering both 
arm's length transactions and informal interactions, i.e. traded and un-traded ones. In fact, Uzzi $(1997,59)$ states that:

The best way for an organization to link to its network is by means of embedded ties, which provide better access to the benefits circulating in the network than arm's-length ties. The optimal network structure to link to is a mix of arm's-length and embedded ties, because each type of tie performs different functions: Embedded ties enrich the network, while arm's-length's ties prevent the complete insulation of the network from market demands and new possibilities.

There is evidence to suggest that traded interactions are a pre-requisite for successful informal knowledge sharing (Lissoni 2001; Li, Poppo, and Zhou 2010). Joint projects between organizations increase trust among employees and informal networks are developed (Cross, Borgatti, and Parker 2002; Allen, Andrew, and Gamlen 2007). Thus, it is expected that joint projects foster an alignment of norms, codes and identities (Wenger, McDermott, and Snyder 2002). In the specific case of interaction between firms and universities, Breschi and Lissoni (2001) are critical of the taken-for-granted assumptions and point out that knowledge flows mainly through pecuniary channels (consultancy, joint research, formal research and so forth). Quoting Breschi and Lissoni's (2001, 993) critique:

...the so-often cited face-to-face contacts may serve only to ease the access to information about who knows what and where is employed, which is the only public good.

Continuing with this line of thought, what appears to be involuntary KS are actually well-regulated knowledge flows (Breschi and Lissoni 2001), especially those coming from TC-firm interactions. Another interesting result from Lissoni's work is the fact that public labs and universities are absent from the communities in which the externalities occur and other studies confirm this point. The Belussi and Sedita (2010) study on the linkages in the Emilia-Romagna regional innovation system showed that the firm-to-TC links, in the form of R\&D projects and research activities, are much more intensive than the firm-to-firm ones. Jenkins and Tallman (2010) argue that knowledge flows are more effectively conveyed between formal alliance partners, even within a cluster, as this type of channel is more productive than those between partners based upon informal interactions (Almeida and Kogut 1999; Gomes-Casseres, Hagedoorn, and Jaffe 2006). Formal R\&D collaboration (Inkpen and Tsang 2005; Kesidou, Caniëls, and Romijn 2009; Trippl, Todtling, and Lengauer 2009), such as that which exists between TCs and co-located firms, are also important mechanisms for the exchange of knowledge.

\subsection{Clusters and the role of firms}

Ronde and Hussler, (2005) emphasize that deliberate actions, rather than unintended actions, through externally oriented relational interactions, increase regional innovativeness significantly. In other words, 'certain regional conditions are necessary but are not in themselves sufficient when no systemic contacts are facilitated' (Ronde and Hussler 2005, 1163). Consequently, the mere presence of TCs seems to be a necessary, but not sufficient factor, and linkages between institutions and firms are required. This idea is emphasized by Cooke $(2005,1129)$ when he mentions that the innovation capability on a regional geographical scale is relational not containerized. 
How can a firm participate in this learning process? A firm's internal resources are related to the concept of AC (Cohen and Levinthal 1990), defined as 'the ability of a firm to recognize the value of new external information, assimilate it and apply it to commercial ends' (128). This means that internal capabilities are central to the firm's technological capacity and enhance the firm's ability to assimilate and exploit external knowledge. The firm's internal resources therefore determine the possibility of using and exploiting external knowledge and thus improving innovation in firms (Cohen and Levinthal 1989, 1990; Klevorick et al. 1995). Von Hippel (1988) indicates suppliers, customers, competitors, universities and research centres as key external knowledge sources. This idea, from the strategic management perspective, is empirically backed by studies on clusters. Research shows that spatial proximity enables the transfer of tacit knowledge and facilitates the exploitation of knowledge spillovers (Maskell 2001; Malmberg and Maskell 2005) and that direct contact between partners is required for the success of research collaborations (Pisano, Russo, and Teece 1988). Nevertheless, recent evidence (Giuliani 2007) suggests that firms in clusters exploit external resources in different ways, i.e., they have the potential to exploit resources, but the extent to which they do so varies. This theoretical point is very important since co-located firms operate in environments in which they maintain frequent and multiple relationships. Nevertheless, the literature on clusters has traditionally taken for granted the idea that territory influences firms (Lawson 1999; Maskell and Malmberg 1999), i.e., all firms can effectively access these external resources. Thus, the $\mathrm{AC}$ construct acts as a moderating construct that enables access to external assets. In other words, the amount and effect of external knowledge flows are unequally distributed across the population of co-located firms and thus, a firm's AC is a potential source of competitive advantage, because of the external knowledge that can be accessed. Therefore, the question is: what types of firms are those that access and exploit local TCs? Which specific firm resources can explain or predict the effective access and exploitation of local TCs?

In order to understand a firm's AC, different contexts and focuses have provided a variety of types of firms and variables analysed, and thus the results are heterogeneous. First, from the point of view of SMEs, different authors have considered non-R\&D variables addressing a firm's resources and technological competences. Bougrain and Haudeville (2002) found that the existence of a design department in a firm, which is more oriented towards the development and improvement of existing products, is a first attempt to structure a firm's innovative capability, so that the qualified employees working there are more able to understand external information and absorb it to improve firm performance. This fact is also pointed out by Lundvall and Nielsen (1999), who emphasized the role of an educational and training policy to give people within the organization a basis on which to introduce innovation. All this evidence is also consistent with the findings of Giuliani and Bell (2005), Giuliani (2005, 2007) and Hervas-Oliver and AlborsGarrigos (2009), who pointed out the important role of a firm's (internal) knowledge as a basis for utilizing external resources. Therefore, it can be stated that a firm's internal resources enables the acquisition of external resources, as co-located firms engage in linkages within innovation systems to foster innovation. A firm with a higher level of AC is more likely to exploit external knowledge flows. This paper sheds light on the issue of how firms in low-tech clusters access TCs as external sources of knowledge in order to complement their limited R\&D capabilities. 
The research design adopted these aims to provide new empirical evidence on the issues contained in the following hypothesis:

Hypothesis 1 Access to TCs in clusters requires some level of knowledge in order to absorb the available resources. Therefore, a firm's internal resources mediate the access to external tech infrastructure in clusters.

\section{The Spanish ceramic tile cluster and its TCs}

\subsection{Why Spain and the VR?}

Why is the VR and Spain of interest for studying clusters? In Spain, around 35\% of jobs in manufacturing are found in IDs; $70 \%$ are small firms and $20 \%$ are mediumsized firms within these IDs. In addition, IDs have the largest share of Spain's total employment in the leather and footwear sectors $(85.2 \%)$, textile and clothing $(50.4 \%)$, household goods $(43.9 \%)$ and musical instruments and toys $(42.3 \%)$. The highest number of IDs by region in Spain is found in the VR (53 IDs and $25.9 \%$ of the Spanish IDs). In the VR, IDs account for $37.6 \%$ of the Spanish employment in districts, with a concentration of $79 \%$ of the employment in the leather and footwear industry, $68 \%$ in the household sector (Boix 2009), or $92 \%$ of the total ceramics (Hervas-Oliver and Albors-Garrigos 2008). In addition, the highest concentration of TCs is found in the VR (Mas-Verdú 2003).

\subsection{TCs in the VR}

The VR has 14 TCs supported by the IMPIVA (Small and Medium Size Enterprise Institute), a branch of the Industry Regional Government. These TCs are integrated within the regional tech infrastructure, offering specialized tech services based on research, development, innovation, testing, information and so forth. We found TCs for the footwear industry (INESCOOP), ceramics (ITC), furniture-wood (AIDIMA), textile (AITEX) and others which focus on other manufacturing industries, such as food, plastics, optics, electric technology, ICT, logistics, construction or packaging. In order to have an international benchmark to set the context of analysis, the IMPIVA network of TCs is similar to the ERVET (Ervet 1997) in the EmiliaRomagna region (Italy), or the network of research infrastructures in BadenWürttemberg [3] (Fraunhofer Institutes, Steinbeis Foundation or Industrial Research Centres, etc.). These TCs are SME-oriented and their activities include innovation and other related activities to support local-regional SMEs.

Why then are the TCs in the VR different? The main point to understand about the VR TCs is that these institutes are particularly focused on one single industry or knowledge domain, i.e., vertical TCs. In this case, the TC studied is "clusteroriented', due to the fact that the ceramic tile industry is represented by a cluster in which external economies are relevant to the development of the local production system.

Overall, the revenue from TCs in 2009 amounted to 127.5 million Euros, which represents an increase of 8.1 million Euros compared to last year. Of this amount, $54 \%$ corresponded to the sales revenues from their activity with private companies (R\&D projects, testing and laboratory services, advising, training, etc.) and the rest came from public funds (58.4 million Euros) from the Valencia Government (31\%), 
the Government of Spain $(10 \%)$ and the EU (5\%). The quintessential role of TCs is the development of R\&D projects. The VR TCs have more than 1600 employees (more than 70\% are higher degree full-time employees (FTEs)) and have participated in fairs (57), organized 204 conferences and congresses, published 271 articles in peer-reviewed journals and directed 36 doctoral theses (Redit 2009).

The Institute of Ceramic Technology (ITC) is a decentralized territorial infrastructure founded as an industry-base firm association. Thus, the SMEs which belong to the associations which control the ITC are part of the General Assembly and provide the president and the members for the board of directors, together with some institutional governmental representatives. This bottom-up approach is key to ensuring the necessary feed-back between SMEs and the TC.

The ITC is located in the Castellon province within the VR. Castellon concentrates $90 \%$ of the ceramic tile production in Spain and is one of the most important ceramic clusters in the world (Meyer-Stamer, Maggi, and Seibel 2004). During the period between 1995 and 2006, the ITC conducted more than 700 R\&D projects (including basic research on materials, applied research on decoration and production processes, scientific trials and material and product tests) which accounted for a turnover of more than $€ 14 \mathrm{~m}$. According to ITC statistics, the industries using the ITC, in order of revenues, are: glazing $(40 \%)$, ceramic tile $(37 \%)$, pigments and basic chemical raw materials $(15 \%)$, ceramic equipment manufacturers $(2 \%)$ and others $(6 \%$, clay producers, sanitary products, etc.). The core importance of the glazing industry is also emphasized by the fact that the industry has 26 firms, while the ceramic tile industry, in second position, is represented by more than 200 firms. The ITC owns 20 patents which have been commercialized in the global ceramic industry (ITC Internal Report). Although the core institution is the ITC, the cluster also includes other institutions that support and foster innovation, as noted in several empirical studies (Gallego 1997; Tomás-Carpi et al. 1999; Meyer-Stamer, Seibel and Maggi 2001; Albors-Garrigos 2002; Hervas-Oliver 2004; Albors-Garrigos and Hervas-Oliver 2006).

The ITC, with 146 FTEs (70\% with university degrees and $17 \% \mathrm{PhD})$, completed 46 public projects, earning 3,656,683 Euros in revenues and undertook 68 R\&D projects valued at 3,034,713 Euros with 76 different SMEs. From 2006 to 2008, the ITC undertook 24,265 lab tests, presented 59 papers in specialized forums and congresses and published 40 peer-reviewed articles in leading chemical scientific journals. In addition, from 2006 to 2008 , the ITC provided 1300 students with more than 2000 hours of training. In order to manage external knowledge, the institute acquired more than 1500 scientific articles, 350 documents about patents and was registered in 120 publications. The ITC is the most active knowledge broker in the Castellon cluster (VR) and specifically focuses on glazing and ceramic technologies, providing a cutting-edge knowledge advantage to the co-located firms (ITC 2008).

Spain is not only one of the main world producers and leaders in the ceramic tile industry in Europe (number one in Europe, with regard to production in square metres and the second world producer after China; ASCER 2005), but also the largest world consumer per capita at $8.2 \mathrm{~m}^{2}$ per inhabitant. The Castellon cluster, which is cited in several empirical papers (Albors-Garrigos 2002; Giner and Santa María 2002; Russo 2004; Albors-Garrigos and Hervas-Oliver 2006; Hervas-Oliver and Albors-Garrigos 2007), has been recognized as an ID phenomenon 
(Ybarra 1991; Benton 1992; Giner and Santa María 2002; Hervas-Oliver and AlborsGarrigos 2007). The cluster is shaped by an area of approximately $30 \mathrm{~km}^{2}$, directly accounts for 36,000 industrial jobs, and has more than 300 firms belonging to various auxiliary industries related to ceramic tile production (ceramic producers, glazing suppliers, clay providers, ceramic machinery suppliers, transport agencies, distributors, etc.).

The ITC serves the co-located industries, especially ceramics and those related industries such as glazing (chemical), clay (mining) or construction, i.e., the main agents in the ceramic value chain. The ITC provides research and development, testing, product development, information, design and other value activities to local firms. In addition, educational centres offer special courses in ceramic tile production, such as a Ceramics Chemical Engineering degree by the local University Jaume I which uses the ITC for internships and technical training transfer. This degree is unique in Europe because of its specificity and application to the industry. The ITC TCs in the VR transfer knowledge to SMEs and are, in part, a branch of the regional R\&D policy of the Valencia Government, although the majority of funds come from competitive programmes at national and European levels.

The Spanish glazing industry, located in the Castellon cluster, is a world-leading industry with extended operations in other clusters. Furthermore, Chinese development has partially benefited by the contributions made by the Spanish glazing industry in China, as well as by the Italian ceramic equipment producers. Together, Spain and Italy (each country led by their respective clusters, Castellon and EmiliaRomagna) represent $72 \%$ (ASCER 2005) of the ceramic tile exports worldwide, and around $90 \%$ of the European ceramic tile production (ASCER 2005). The industry is basically formed by ceramic tile producers (final production stage), ceramic equipment suppliers and glazing materials suppliers with a high degree of vertical disintegration. There are around 220 ceramic firms located in the area with around 26,000 workers directly engaged in the industry. Auxiliary firms also occupy a prominent position in innovation. These are comprised of 26 local glazing firms which employ 3487 workers (ASCER 2005) and 41 ceramic equipment manufacturers which employ around 1250 workers (Albors-Garrigos 2000; Hervas-Oliver and Albors-Garrigos 2008).

The ITC presents an unusual organizational structure and ownership which is one of the key factors underpinning its success. Firstly, the institute ownership and management is a combination of both private and public bodies, since the local university is only a part of the institute. The ITC was first established by the Regional Government as the Technological Institutes Network created to promote and stimulate, top-down, the regional industries in the 1980s, although it originally came from a spin-off of the University of Valencia in the $1960 \mathrm{~s}$.

On the one hand, the private body which has management and ownership functions in the ITC is the Ceramic Industry Research Association (AICE), whose members are several private trade associations interested in research in ceramics (ceramic producers, glazing firms, architectural and decoration, chemical and other associations representing the industries involved). On the other hand, the public body, which also coordinates and shares ownership in the ITC, is the public Jaume I University (henceforth UJI) through the Ceramic Technology University Institute. In total, there are 146 full-time staff members in the ITC, 130 from the private AICE and 16 from the public UJI. The employees are lecturers (20), chemical engineers (40), 
other graduates and engineers (20, design engineers, arts and decoration graduates, industrial engineers, etc.), qualified research assistants (20 economists, lawyers, marketing specialists, grant-assisted students, assistants from vocational training centres and others), who form part of the administration staff (36). The structure includes a Materials Engineering Department for basic research, the Processes Engineering Department for applied research and the Management of Technology Transfer Department, which is a part of the Management and Coordination Department.

The ITC research services have a special type of organization, involving all the economic actors and agents from the ceramic industries in a complex system which works well. First, the UJI, which is the public owner of the ITC, offers a degree in Chemical Ceramics Engineering, the only degree of such characteristics in the world. The basic courses are taught in the university by all the engineering departments. Nevertheless, the specialization or major in chemical ceramics, as well as the courses for post-graduate advanced studies and $\mathrm{PhD}$, is imparted in the Ceramic Technology University Institute (the body which represents the UJI within the ITC) by the Chemical Engineering Department. The interesting point is that the lecturers in this department are also researchers in the ITC, and they combine part-time posts and/or periods of time in which they focus only on one of the two positions. This creates a mechanism for the transfer of knowledge from real-life projects and research to the students. It can be said that the lecturers are the link between the university and the ceramics industry, and at the same time between the industry, the ITC and the students. Nevertheless, these lecturers share the projects with full-time ITC researchers from the AICE. This avoids dependency on only academic interests and visions and also contributes to enriching the complex system of interactions and innovation. The vast majority of the ceramic tile engineers involved in the process of ceramic tile production and the engineers in the glazing firms have passed through the Ceramic Technology University Institute (or Chemical Engineering Department). There is also considerable mobility of researchers from the ITC to private glazing and ceramic tile firms. This helps the process of knowledge transfer, as the best practices are rapidly disseminated within the cluster. It also encourages an informal networking of relationships, trust, common vocabulary and shared goals, which enrich the process of knowledge transfer. All this promotes a fluid circulation of tacit and explicit knowledge, based on the same language, culture and understanding, implicitly working towards the same targets. In addition, it should be noted that today, the ITC is a mixture of top-down and bottom-up initiatives, due to its unique ownership system by local authorities (including the university) and trade associations.

The true strength of the Castellon ceramic cluster thus lies in its dense network of ties between TCs and other support organizations and co-located firms (MeyerStamer, Maggi, and Seibel 2004; Hervas-Oliver and Albors-Garrigos 2007), which involves a mechanism for the diffusion of innovation that would be very difficult to replicate in a different context. This has been confirmed in the interviews and other informal talks conducted. The university plays the key role of providing skilled engineers involved in ceramics research and helps with research in the ITC, thereby channelling the research conducted in the cluster through an institutional promotional mechanism. This avoids academic self-interest, and inserts the ITC within the cluster's inter-firm networks. In other words, the ITC constitutes the open and 
collective research lab in the cluster, and the presence of the university in the supposed 'third role' is fruitful but limited.

\section{Empirical design}

\subsection{Sample}

The study consists of 80 semi-structured interviews conducted with firms co-located in the Castellon cluster firms in order to make an assessment of the local RTO (ITC) utilization by co-located firms in the ceramic cluster of the region, and their general perception of this particular asset for promoting the cluster. The authors conducted informal talks with the more important industry agents (managers of the leading firms and directors of the different trade associations, policymakers and other key informants). The sample comprised co-located ceramic and glazing firms in the cluster and was based on the list of ceramic tile manufacturers and glazing firms provided by the cluster trade associations (ASCER and ANFFECC). Eventually, 64 ceramic (low-tech industry) and 16 glazing firms (medium-high tech), chosen at random, agreed to participate in the study, although the glazing firms neglected to provide some key figures. The 64 firms of the sample represent around $40 \%$ of the ceramic tile population and the 16 glazing firms of the sample constitute the $80 \%$ of the real population in the frits and glazing industry [4]. The interview's questions were referred to the activities developed by the ITC in its role to support the cluster. During the interviews, the questions asked referred to the role played by the ITC, the firm's opinion of its role, the type of utilization and other aspects.

Table 1 shows the sample of firms in the study. Of the sample, $78.12 \%$ are firms with less than an average of 100 FTEs, and the largest group is that composed of between 50 and 99 FTEs ( 28 firms, $43.75 \%$ of the sample). Only 5 firms $(7.8 \%$ ) have more than 200 FTEs. The study therefore focuses primarily on SMEs.

The empirical work covers two different stages. First, a more qualitative approach through formal and informal interviews, in which the glazing firms also participated and second, a quantitative empirical exercise with the ceramic firms co-located in the cluster.

Table 1. Sample of firms.

\begin{tabular}{lcc}
\hline Glazing producers & Number of firms & Firms \\
\hline Size & & 16 \\
More than 200 employees & Firms in each group & Percentage of firms \\
Ceramic producers size & 22 & 34.37 \\
Less than 50 & 28 & 43.75 \\
$50-99$ & 30 & 78.12 \\
Total less than 100 & 9 & 14 \\
$100-200$ & 5 & 7.8 \\
More than 200 & 64 & 100 \\
Total & &
\end{tabular}

Source: own.

Note: Size on number of employees. 


\subsection{The qualitative approach: Results of interviews}

The interviews focused on the firms' technological support obtained from TCs. All interviewed glazing firms $(100 \%)$ make frequent use of the ITC, including scientific trials, product and material testing, and $\mathrm{R} \& \mathrm{D}$ projects outsourced to the centre. It is noteworthy that when a firm uses the ITC services to transfer knowledge, it signs a confidentiality agreement and formal contract. This explains why these are traded and market-based flows of knowledge, although we recognize from the interviews that the un-traded interdependencies reinforce the transfer of knowledge in the sense that both parts talk the same language, i.e., they have common understandings and goals. In addition, most of the glazing engineers have been trained in the ITC and have social connections to the people working in the ITC labs. Apart from the specific functions, other services such as information, product certification, project funding, patenting and licensing consultancy and others were also used by the glazing firms. In general, they emphasized the crucial importance of the centre for research and innovation. Around a third of the research projects in the ITC are undertaken in collaboration with ceramic tile firms and the rest are conducted by glazing firms. Alternatively (Table 2), the ceramic tile firms declared in $31.25 \%$ of cases that they have never used the ITC; $34.37 \%$ of the firms have used it for product certification and information on materials, products or contacts; $21.875 \%$ have used the ITC occasionally for research projects as required and only $12.5 \%$ of the sample makes frequent use of the ITC for research projects as part of their innovative strategies. Around $16 \%$ of the ceramic tile firms considered the ITC as a core competence in the cluster, $40 \%$ thought it as an important research support asset and the rest $(34 \%)$ considered the institution as good. $10 \%$ declared indifference towards the ITC.

All the ceramic tile firms interviewed considered the glazing industry their key suppliers and the core knowledge transceivers. Thus, the main source of external knowledge acquisition is based on the interaction of the ceramic firms with glazing firms in the cluster. In fact, all the firms stated that informal and close relationships are always maintained with several glazing firms at the same time. Moreover, $30 \%$ of the interviewed firms, specifically the largest in size, also declared that formal contracts are often signed jointly with glazing firms for the development of certain designs and products on an exclusive basis. In this sense, the flows of knowledge are both traded and un-traded, since the glazing firms provide part of the design for free process as a way of promoting the acquisition of the glaze. The fact that tile firms make less utilization of the ITC, compared to the intensive utilization of the centre by the glazing firms, is consistent with the technological capacities of the ceramic tile firms, which are mainly focused on design and decoration functions.

Table 2. IITC utilization by ceramic tile firms and their size.

\begin{tabular}{lc}
\hline ITC declared use & Frequencies \\
\hline Never & $20(31.25 \%)$ \\
Product certification and other basic services & $22(34.37 \%)$ \\
R + D occasionally & $14(21.875 \%)$ \\
R $+D$ frequently & $8(12.5 \%)$ \\
Total & $64(100 \%)$ \\
\hline
\end{tabular}

Source: own. 
The ceramic tile producers are closely related to the glazing firms and are secondary to the ITC. The use of this public and open lab is a part and extension of the strategies of acquiring new knowledge from external sources, and also of complementing and enriching them through the glazing firms. Consequently, glazing firms are more engaged in research projects with the ITC.

The linkages developed by the ceramic and glazing firms can produce innovations or products needed by the ceramic tile producers, or trigger a continuation of the collaboration with the ITC to acquire new knowledge. Secondly, the glazing firms outsource research projects to the ITC individually to complement their knowledge and to offer new advances to clients. Consequently, the innovation process is a complex interaction between the ceramic producers, the glazing firms and the ITC. The ceramic tile producers probably do not know how much of the knowledge generated by the ITC is disseminated to them through the glazing industry which acts as a carrier industry á la Rosenberg (1976). Therefore, we can map the innovation process as starting with ceramic tile requirements, which, in order to be fulfilled by the glazing industry, require an initial process of informal interaction along the existing informal inter-firm networks that foster innovation. There is also a possible process of interaction in which the ITC takes part, linking the two industries and making the cooperative linkages between ceramic and glazing producers more explicit and formal.

The results exactly match those addressed in the theory. First, the SME ceramic firms in the cluster present, in general, weak ties with the ITC for research purposes. Second, as claimed in the literature, the user-producer interactions (Von Hippel 1988) are the interactions that are most observed between SMEs (Izushi 2005; Olazaran, Albizu, and Otero 2009). Third, evidence suggests that the more knowledge-intensive the industry in the cluster, the greater the use of the research infrastructure (Coenen, Moodysson, and Asheim 2004; Asheim and Coenen 2005). This is in line with Nelson's (1993) typology of firms which characterizes the technical change process, making special mention of the firms which produce commodities, i.e., firms with minor process and product innovations called bulk commodities (i.e. ceramics) and the providers of technology and advanced services (i.e. glazing firms) which are equipment and specialized input suppliers. The latter industry is the one mainly responsible for promoting innovation through the value chain, and it can play a prominent role in upgrading the cluster and providing knowledge spillovers to the rest of the co-located industries. There is a sector dynamism observed in 'low-tech' sectors due to cross-sector linkages (Pietrobelli, Rabelloti, and Giuliani 2005) with co-located glazing firms. Thus, the relevant knowledge base in many industries is spread across linked sectors (Smith 2000) that transfer knowledge and reinforce one another, which is the case described here. Fourth, the glazing firms diffuse knowledge within the ceramic sector, bridging TCs and ceramic SMEs, and fifth, some ceramic firms - those with a better knowledge base - also access the TCs.

Porter (1990) remarks on the role of auxiliary and related industries in clusters to explain cluster strength. Thus, advanced industries could reinforce the system and contribute to other types of industrial development in geographical clusters. Therefore, the glazing providers are the gatekeepers who create and diffuse knowledge in the cluster. The concept of 'gatekeepers of knowledge' (Allen 1977) refers to individuals who are at the core of the information networks and are exposed 
to external sources of information. Clusters and their internal organizational structure affect the existence of leading firms (Boschma and Lombooy 2002; Belussi, Gottardi, and Rullani 2003) or technological gatekeepers (Allen 1977), which present stronger capabilities and, consequently, access a larger set of external information and knowledge sources. The gatekeeper organization is well-linked to global knowledge sources as well as to local organizations (Giuliani 2005; Munari, Malipiero, and Sobrero 2005). These gatekeepers have high ACs for accumulating knowledge (Lazerson and Lorenzoni 1999) and diffusing it to the components of the network (Giuliani 2007)

It is evident from the interviews that the innovation systems primarily work at two levels: firstly, the glazing-ITC interactions and secondly, the glazing-ceramics interactions. The glazing industry acts as a technological gatekeeper in conjunction with leading ceramic firms, and therefore, the diffusion mechanism is based on a mixture of un-traded and traded relationships carried out by the glazing industries to transfer knowledge to the ceramic firms. Consequently, most of the co-located ceramic firms can access the knowledge provided by glazing firms in formal and informal (traded and un-traded) combinations. Nevertheless, only a few firms can access the traded (pecuniary transactions) flows of knowledge provided by the ITC. This begs the question of why some ceramic firms can access them while others cannot.

\subsection{The quantitative research: A model describing the interactions between $T C$ s and ceramic SMES}

In this part of the study, 64 ceramic tile firms participated in an assessment of their internal resources, i.e., AC for accessing the local ITC. The variables utilized are shown in Table 3.

What types of variables can effectively represent SMEs in low-tech sectors? The firm's resources and capabilities are adapted to the specific patterns of the sector (Amit and Shoemaker 1993). This paper studies the SMEs in a low-tech traditional cluster (ceramic tile) and consequently, the variables go beyond the R\&D variables which are not frequently considered in these types of low-tech SMEs. Tidd (2000) classified internal competences into three categories: (a) organizational competences (managerial systems, skills, etc.); (b) market competences and (c) technological competences, mainly derived from in-house R\&D activities. The firm-distinctive competences or, main internal resources, construct is based on the idea that hardly any SMEs have R\&D departments. As a result, the main internal variables were defined as non-R\&D activities, covering specific human resources with tertiary education (skills), mainly in production and management, and their marketing capabilities (marketing).

First, on looking at SMEs, some scholars have bypassed only R\&D intensity in their studies addressing technological competences. Bougrain and Haudeville (2002) found that R\&D intensity does not influence the future prospects of a project in SMEs, which is similar to the findings by Rocha $(1999,268)$. In contrast, the skilled employees working in the firm are more capable of understanding external information and absorbing it, thereby improving the SMEs' performance. Similarly, this fact was also pointed out by Lundvall and Nielsen (1999) who emphasized an educational and training policy that provides people within 
Table 3. Variables utilized in the study with description and scale.

\begin{tabular}{|c|c|c|}
\hline Variables & Description & Scale \\
\hline \multicolumn{3}{|c|}{ Internal resources (absorption capacity) } \\
\hline Skills & $\begin{array}{l}\text { Proportion of workforce (FTEs) classed } \\
\text { as technicians or scientists: number of } \\
\text { employees with higher education } \\
\text { engaged in production or manage- } \\
\text { ment, including engineers, econo- } \\
\text { mists, lawyers, etc. }\end{array}$ & $\begin{array}{l}\text { Metric variable } \\
\text { Expressed as percentage } \\
\text { of the total FTEs }\end{array}$ \\
\hline ISO & $\begin{array}{l}\text { Proxy for organizational routines: } \\
\text { whether the firm has the ISO9000 or } \\
\text { not; yes }(1) ;(0) \text { otherwise. Control } \\
\text { variable }\end{array}$ & Nominal binary variable \\
\hline Manager & $\begin{array}{l}\text { Whether the firm's management is } \\
\text { overlapped with property (equity). Is } \\
\text { the company run by professional } \\
\text { management?: yes }(1) ;(0) \text { otherwise. } \\
\text { Control variable }\end{array}$ & Nominal binary variable \\
\hline Marketing capacity & $\begin{array}{l}\text { Marketing function in the company. } \\
\text { Likert scale from } 1 \text { (non-existence) to } \\
5 ; 1=\text { there is no marketing function } \\
\text { in the firm, to } 5=\text { the function } \\
\text { includes brand building, marketing } \\
\text { research activities, product } \\
\text { management, etc. }\end{array}$ & $\begin{array}{l}\text { Ordinal variable } \\
\text { Referring to the average } \\
\text { of the last } 3-5 \text { years } \\
\text { 5-point Likert scale }\end{array}$ \\
\hline Design & Technological capacity of the firm & $\begin{array}{l}\text { Metric variable } \\
\text { Percentage of a firm's } \\
\text { production in which } \\
\text { the company uses its } \\
\text { own design technol- } \\
\text { ogy versus outsour- } \\
\text { cing it. }\end{array}$ \\
\hline $\begin{array}{l}\text { Technology centre } \\
\text { accessed (ITC) }\end{array}$ & $\begin{array}{l}\text { Type of links with the local TC to access } \\
\text { to external knowledge. Scaled from } 0 \\
\text { to } 3 \text {, as a proxy for meaning: (0) No, } \\
\text { never; (1) Yes, occasionally for getting } \\
\text { information, obtaining product, } \\
\text { quality certifications or other } \\
\text { consultancy services; (2) Yes, occa- } \\
\text { sionally for R\&D matters and (3) Yes, } \\
\text { it is used on a continuous basis for } \\
\text { R\&D, trials and tests and it is part of } \\
\text { our technological strategy. }\end{array}$ & $\begin{array}{l}\text { Ordinal variable } \\
\text { Referring to the average } \\
\text { of the last } 3-5 \text { years } \\
\text { 4-point Likert scale }\end{array}$ \\
\hline \multicolumn{3}{|l|}{ Control } \\
\hline Size & $\begin{array}{l}\text { Measured as average number of FTEs. } \\
\text { Control variable }\end{array}$ & $\begin{array}{l}\text { Metric variable } \\
\text { Referring to the average } \\
\text { FTEs }\end{array}$ \\
\hline
\end{tabular}

Source: Compiled by the authors.

organizations with the basis on which to introduce innovation. Thus, higher levels of training also reinforce the creation and exploitation of external knowledge, although there is no empirical evidence in the cited study.

Similarly, Terziovski (2010) shows that, in SMEs, there is no correlation between technological capabilities and SME performance. In fact, it is claimed that SMEs 
view technological capability as an enabler, rather than a driver, of their performance. SMEs should not view innovation from an exclusively technological perspective, but rather from a strategic and market-driven perspective (Bessant and Tidd 2007). Souitaris (2002) provides evidence to suggest that the strength of supplier-dominated firms lies mainly in marketing, external communication variables and the competitive environment, thus indicating that SMEs were market - rather than technology - driven, which is specifically this case. This is consistent with the current literature focus on SMEs in LMT clusters (Parrilli, Aranguren, and Larrea 2010,365 , for the furniture cluster in the Basque Country) which claimed that many firms did not consider the role of the RTO's (CIDEMCO) R\&D activities as a key driver of their competitiveness, as their innovation needs are more focused on design and marketing (MIK 2006).

Critics of the use of R\&D intensity to explain innovation focus on the fact that the correlation found between the mentioned variables is inferior to $0.3(10 \%$ of the innovation variance) which is rather weak evidence (Brouwer and Kleinknecht 1996; Roper and Love 2002; Raymond and St-Pierre 2009). In order to solve the problem of hidden innovators (Arundel, Bordoy, and Kanerva 2008), which are those firms that achieve innovations without conducting $R \& D$ expenditures, some studies have begun to use other variables than just $R \& D$ as inputs for explaining a firm's R\&D cooperation (Veugelers and Cassiman 2005). Overall, this linear R\&D-based innovation paradigm has been challenged from different perspectives. Nontechnological forms of innovation also contribute to a firm's performance upgrading (Piva and Vivarelli 2002; OECD 2005) and thus, innovation can be observed as a phenomenon occurring in the LMT sectors (Kirner, Kinkel, and Jaeger 2009). Jensen et al. (2007) distinguish between the 'Science, Technology and Innovation' and 'Doing, Using, Interacting' modes of innovation, and consider the latter to rely on process and experience-based know-how, which mainly refers to the LMT sectors. Continuing this line of inquiry, the Oslo Manual (OECD 1994, 2005, 65-66) states that dividing R\&D activities from downstream activities (marketing, design, etc.) can, in some industries, be a valid process. In this context, the process of innovation is well described in Albaladejo and Romijn (2000) who posit that: "A substantial part of the learning may not take the form of well-defined R\&D programmes and other formalized technological efforts. Informal and incremental problem solving and experimentation take place on the shop floor and are closely associated with production. This is, a fortiori, the case in small companies that do not have the resources and organization to mount large $R \& D$ and human resource development programmes' (4-5). This non-R\&D view on innovation is supported by the fact that economy in real terms is more than $90 \%$ based on the LMT sectors (Robertson, Pol, and Carroll 2003).

Therefore, because the firms involved in this study are basically SMEs involved in low-tech industries (or supplier-driven, in Pavitt's terms), the study attempts to depict resources other than $\mathrm{R} \& \mathrm{D}$ activities. The selected variables were also recommended by the key informants in the cluster. The internal resources are measured by variables referring to human resources and their level of skills, as well as the marketing function, the firm's technology and its organizational routines, such as the existence of the ISO quality standard or the type of manager (professional versus family member) running the firm. In this industry, we term as Design the technology mainly based on design and decoration activities. The Design variable represents the 
percentage of production for which the firm uses its own design (production and decoration) facilities which, according to informants, is an indication of a firm's technology in this specific sector, and the variable Skills represents the percentage of FTEs with higher education. The Marketing variable describes the marketing function of the firm. The reason for selecting the described variables is a result of the informants' opinions and our desire to better describe a firm's resources in the selected industry. The selection of the variables is also justified according to the reviewed literature which has depicted a firm's internal resources without R\&D variables. As such, besides the aforementioned studies, Santamaría, Nieto, Barge-Gil (2009) use design activities and hiring skilled personnel when addressing SMEs in LMT sectors. Freel (2003), among others, uses the percentage of skilled personnel (both technicians and technologists) and Freel (2005) also uses marketing skills. In the latter two studies, the samples were SMEs. Lastly, Camisón (2004) employs a marketing and production-distinctive-competences focus on SMEs for low-tech firms in Spain. Small firms usually present a commercial endeavour rather than a purely technological one, and the commercially significant innovation in manufacturing is technologically incremental rather than radical (Audretsch 1995; Love and Roper 1999). As such, we try to depict all these dimensions with the variables presented, thereby reflecting the type of external knowledge accessed by a firm through its internal resources, which configure its AC.

The next set of variables measure the ownership-management function and quality management activity. For operative reasons, we use a definition of family business similar to that used by Gómez-Mejía, Larranza-Quintana, and Makri (2003) or Ang, Cole, and Lin (2000): that businesses in which people share at least one surname have majority ownership. Thus criteria ensured that family members had the majority of the property of the company and that there were family members in the management (board of directors) or the control (board of governors) of the firm. This definition is in line with the one used by Lambrecht and Lievens (2008) who define a family firm as a business where the family has a decisive influence in the daily management and ownership. Arnold (1998) claims that SMEs tend to underestimate professional advice, which they occasionally see as a threat to the management's authority. Hausman (2005) points out that power and decision-making in SMEs is concentrated in the hands of an owner or a manager. Frequently, owners reject the advice of others, and are loath to delegate authority or decision-making. Furthermore, excessive involvement of the owner in decisions at the operating level, and family considerations may reduce the tendency to take risks. It is likely that this will have an effect on decisions to either approach or avoid technology providers. On this issue, Kalantaridis and Pheby (1999) state that the ability to bring existing regional resources and capacities to companies is largely determined by the particular kind of system used by the owner or manager: "indeed, the attitude of the owner/manager, characterized by a craftsman lifestyle approach to business, combined with risk aversion, was identified as the key obstacle to innovation among non-innovating SMEs' (Kalantaridis and Pheby 1999, 76). The variable Management is operational using a dummy variable to indicate whether the company is run by a professional manager or has some family members in the board of directors. This variable is also part of the existing human resources in the company. 
Quality management is measured by the firm's fulfilment of the ISO 9000 standard (see Table 3). The ISO 9000 certification, ISO, addressing organizational routines, is widely employed in SMEs (Casadesus, Giménez, and Heras 2001). It is meant to improve awareness of the problems of the company, especially in product quality (Vloeberghs and Bellens 1996; Brown, Van Der Wielle, and Loughton 1998), and trigger a better response to the customers' requirements, relations and services or to improve communication and reduce improvization (Casadesus, Giménez, and Heras 2001). Most papers in the innovation literature have linked absorption capacity to the firm's internal resources (Arbussà and Coenders 2007; Vega-Jurado et al. 2008; Hervas-Oliver and Albors-Garrigos 2009). In this case, in SMEs, the ISO is an accessible proxy which, to some extent, measures the organization in SMEs using a dummy variable (see Table 3 ). We controlled for size because innovation performance might benefit from economies of scale and scope (Cockburn and Henderson 1994).

The firms involved in this study are basically SMEs involved in low-tech industry, and for this reason, the study does not focus on R\&D activities. Thus, the external knowledge accessed (ITC) variable represents the type of knowledge accessed by a firm with the ITC. This variable accounts for the nature of the links that a firm has with the available TC. It is scaled as (0) no linkages; (1) occasional, for getting information or product certification; (2) sometimes, for R\&D matters and (3) on a continuous basis for R\&D as part of the firm's technological strategy. The type of linkage determines the knowledge absorbed by a firm and the variable is treated as a scalar one.

A linear multiple regression (ordinary least square, OLS) was run to determine the contribution of each variable, representing the internal resources, or $\mathrm{AC}$, and the level of external knowledge accessed through linkages with the local RTO. The equation model similar to the ones employed to understand access to external flows of knowledge with public research offices (Muscio 2007; Segarra-Blasco and Arauzo-Carod 2008) is expressed as follows:

\section{Access to ITC $=$ Const + Firm's internal resources or $A C+$ Control variables $+\varepsilon$.}

When a linear specification is used, the regression takes the following form (where the endogenous variable is a measure of performance, type of knowledge accessed in this case, subscript ' $i$ ' denotes firms, and $\varepsilon$ is the error) related to the specified variables:

$$
\begin{aligned}
\text { Access to ITC } i & =\text { Const }+ \text { Internal resources }[\beta 1 \text { Skills } i+\beta 2 \text { Design } i \\
& +\beta 3 \text { Marketing }+\beta 4 \text { Manageri }+\beta 5 \text { ISO } i] i+\text { Control }[\beta 6 \text { Size } i]+\varepsilon i
\end{aligned}
$$

First, a set of variables, from coefficients $\beta 1$ to $\beta 5$, accounted for the firm's internal resources in terms of strategy, technology and human resources following the framework of Lane, Koka, and Pathak (2006) and the recommendations described by the informants. Subsequently, $\beta 6$ was entered as a control variable measured by the number of employees, the Size variable, as suggested in other studies (Cockburn and Henderson 1994; Camisón 2004; Escribano, Andrea Fosfuri, and Tribó 2009). 
Table 4. Main descriptive statistics.

\begin{tabular}{lccccc}
\hline Variables & Mean & Standard deviation & Min & Max & $N$ \\
\hline ISO & 0.42 & 0.498 & 0 & 1 & 64 \\
ITC & 1.15 & 1.010 & 0 & 3 & 64 \\
Manager & 0.729 & 0.449 & 0 & 1 & 64 \\
Skills & 0.0696 & 0.04081 & 0 & 0.16 & 64 \\
Design & 0.47 & 0.3806 & 0 & 1 & 64 \\
Marketing & 2.71 & 1.059 & 1 & 5 & 64 \\
Size & 141.27 & 97.5 & 35 & 416 & 64 \\
Frequencies & & & & & Total \\
Variables & Yes & No & & $100 \%$ & \\
\hline ISO & $27(42 \%)$ & $37(58 \%)$ & & $100 \%$ & 64 \\
Manager & $17(27.1 \%)$ & $47(72.9 \%)$ & & 64 \\
\hline
\end{tabular}

\subsection{Multivariate results}

The results of the main descriptive statistics are shown in Table 4. As shown in the table, close to half of the firms $(42 \%)$ have implemented the ISO, most of the companies are run by family members $(72.9 \%)$, the percentage of skilled workers (with university degrees) ranges from $4 \%$ to $6.9 \%$. The average size of the firms (141 FTEs) was still within the typical range for SMEs ( $<250$ FTEs). According to the reflected statistics, the ITC is accessed mainly for non-tech activities (average of 1.15 out of 3 ). We thus observed a constrained access by the SMEs to the studied RTO for technology purposes.

Table 5 presents the different adjusted regression models. The first and second models reflect the effects of a firm's AC on the external resources accessed. The models utilized were tested using stepwise regression. This procedure estimated a model using the minimum number of non-superfluous, and at the same time significant variables (Guillen 1992). The $F$-test in each model suggested that the models, through explanatory variables, were significant in explaining innovation at $p<0.01$. Furthermore, the adjusted $R^{2}$ coefficient indicated that the models presented explained 0.23 (model 1, F-Snedecor 8.12) and 0.25 (model 2, F-Snedecor 4.9) of the variability in the firm's access to external resources (TCs, in this case).

As can be seen from the table, the most important variable in the two models is Skills which scores 7.27 and 7.4 (both statistically significant at $p<0.05$ ). Design is also an important variable with 0.95 and 0.89 in the coefficients (both $p<0.01$ ). The marketing variable was not significant in any model. Only the ISO variable, reflecting the organizational routines, was consistent (coefficient 0.427) and significant at $p<0.1$. Manager is not statistically significant in any model, neither is Size, the control variable. The latter means that the level of formalized procedures or routines in a firm, (ISO), its skills (human resources-based) and technology (through design activities) enables the firm to access external knowledge as part of its technology strategy, making use of the available external resources through TCs in clusters. Therefore, the 'lack of strategic viewpoint in relation to business development' (Rutten 2000) is reflected in the poor utilization of such external R\&D facilities in clusters. 
Table 5. Results of the OLS estimates.

\begin{tabular}{llccc}
\hline Specification model & Variables & Adjusted $R^{2}$ & $F$ & Significance \\
\hline 1 & & 0.233 & $8.12^{* * *}$ & \\
& & Coefficients & & 0.508 \\
& (Const.) & 0.186 & & $0.00^{* * *}$ \\
Design $\beta 1$ & 0.959 & & $0.03^{* *}$ \\
Skills $\beta 2$ & 7.279 & & \\
& & 0.252 & $4.9^{* * *}$ & \\
& & Coefficients & & 0.793 \\
& (Const.) & -0.097 & $0.013^{* *}$ \\
& Design $\beta 1$ & 0.898 & & $0.05^{* *}$ \\
& Skills $\beta 2$ & 7.479 & & \\
ISO $\beta 5$ & 0.427 & & \\
& & & & \\
\hline
\end{tabular}

Notes: $N=64$; dependent variable ITC. The variables not shown in the model were excluded because of their lack of contribution to the model in the adjusted $R^{2}$ through the stepwise procedure in the multiple regression analysis.

* Significant at $p<0.1$.

** Significant at $p<0.05$.

$* * *$ Significant at $p<0.01$.

On the one hand, skills, technology (Design) and organizational routines (ISO) are the most relevant determinants for accessing $\mathrm{R} \& \mathrm{D}$ centres by ceramic firms. On the other, the results make sense and are consistent with the information obtained from the interviews which showed that only the firms with engineers or qualified personnel can utilize TCs to improve technology. Overall, the main message from the results obtained is that firms need a certain level of internal resources or AC (threshold effect) to be able to access certain external knowledge in a cluster, meaning that the internal resources (absorption capacity) limit the type and amount of available knowledge in clusters from the tech infrastructure or TCs. Nevertheless, the research may be handicapped in that it did not consider the soft aspects related to the social capital approach (mutual trust, understanding and so forth).

\section{Conclusions}

This paper explores the interrelationships between SMEs and TCs in a low-tech cluster, and sheds light on how a firm absorbs the available RTO knowledge, analysing to what extent TCs can contribute to promoting innovation in clusters. For this purpose, an analysis of the interactions between the knowledge infrastructure (TCs) and the learning process (firms engaged in absorbing knowledge in clusters) is conducted, employing non-R\&D variables to set the study in an appropriate lowtech context. In addition, this paper offers a novel approach by explicitly considering the traded interactions in clusters. Overall, the results confirm the stated hypotheses and clarified the manner, under what circumstances and to what extent TCs contribute to the cluster's development. 
The interviews described herein confirm that the innovation system works principally at two levels: the glazing-ITC interactions and the glazing-ceramics interactions. Thus, the glazing industry acts as a technological gatekeeper, in conjunction with leading ceramic firms, and that the diffusion mechanism is based on a mixture of un-traded and traded relationships undertaken by the glazing industries to transfer knowledge to the ceramic firms. Therefore, most of the co-located ceramic firms can access the knowledge provided by glazing firms ${ }^{5}$ in a combination of formal and informal ways (traded and un-traded). Nevertheless, only a few ceramic firms can access the traded (pecuniary transactions) flows of knowledge provided by the ITC. First, the most important interactions between co-located firms occur between ceramic firms and their suppliers, glazing firms, which provide knowledge in a user-producer interaction. Second, the glazing industry, i.e., the knowledge-intensive industry in the cluster, is the most important user of the local RTO. These traded and market-based flows of knowledge are reinforced by un-traded flows since both parts talk the same language, and they have common understandings and goals, as Jenkins and Tallman (2010) remark. Therefore, the local KS can adopt a hybrid behaviour (Ibrahim, Fallah, and Reilly 2009; Kesidou, Caniëls, and Romijn 2009) in which, besides pure KS or traded market-based transactions, some overlapping forms of knowledge flows also occur. This fact has received little attention from scholars and consequently, this paper addresses a novel approach to emphasize the role of traded (market-transaction) flows of knowledge as important assets and drivers of innovation in clusters.

The results of the quantitative analysis stressed the following points. First, in the ceramic industry, not all cluster firms can effectively access and exploit the available external knowledge from the TCs, since their internal resources (AC) limit exploitation. Nevertheless, the ceramic firms with a higher AC also access the TCs and contribute to the creation of knowledge. In this case, the firm's internal resources moderate the access to the available knowledge and thus, the stronger the knowledge-base of the SMEs, the higher the probability of engagement in cooperation agreements with an RTO. In the case of the ceramic SMEs, their knowledge base determines which of them can access these specific flows of knowledge. In some way, the latter idea is linked to the debate about how networks work in clusters. According to Morrison (2008), knowledge diffusion is structured and planned within a closed (club), rather than unstructured, network and not all district members access the knowledge that the gatekeepers screen, select and filter. In accordance with Ranaweera and Prabhu (2003), TCs offer simple and complex services to engage users, and thus progressively more complex services are offered as they are needed (Mas-Verdú 2007, 20), covering all different type of services required by small or large firms. Nevertheless, the problem is not the supply of services but the necessary capacity of firms to demand such advance services. In light of our results it can be observed that when demand is scarce, the supply side (TCs) should provide less complex services (laboratory tests to verify safety, quality or environmental certifications) to attract firms while providing also tools to improve the firms' capabilities to understand and thus demand more complex services. Therefore, our conclusions confirm the studies suggesting that interaction is scarce between firms and TCs (Lagendijk 2000; Landabaso 2000; Kaufmann and Wagner 2005; Tödtling and Trippl 2005), especially in clusters (Hassink 1997; Lissoni 2001; 
Arnold et al. 2007; Mas-Verdú 2007; Belussi, Sammarra and Sedita 2008; Parrilli, Aranguren, and Larrea 2010).

Overall, the ceramic low-tech SMEs in the cluster present weak interactions with the local TCs, although they have stronger relationships with suppliers. This result is expected, as the cluster and the studied industry is supplier-driven in the sense described by Pavitt (1984). This paper is consistent with the fact that stimulating the cluster innovation capability by policymaking through the creation of TCs is positive (Camagni 1992). The involvement of co-located firms with TCs upgrades the companies' capabilities (McEvily and Zaheer 1999; Hervas-Oliver and AlborsGarrigos 2009). Nevertheless, as our findings point out, SMEs need a certain level of internal resources or $\mathrm{AC}$ (threshold effect) to be able to access certain external knowledge in clusters, confirming previous studies (Giuliani 2007; Hervas-Oliver and Albors-Garrigos 2009). Therefore, the mere presence of TCs per se is not sufficient. Industries and private initiatives in clusters predominate (Sölvell, Lindqvist, and Ketels 2003; Fromhold-Eisebith and Eisebith 2005) and this corresponds directly to the active role played by firms (Porter 1990), i.e., a bottom-up perspective. Firms are explicitly addressed as part of the cluster's resources. As a result, their activities are partially responsible for improvements in the cluster and for regional competitiveness (Budd and Hirmis 2004), including deliberate links (Ronde and Husler 2005) with institutions and other inter-firm collaboration through networks. Thus, a firm's $\mathrm{AC}$ is a crucial element to effectively make use of local resources. These conclusions support Wolfe's (2009) study carried out on 26 different clusters in Canada [5] which stated:

The mere presence, or absence, of key institutional elements of the local or regional innovation system also affects their innovative capacity and their potential to serve as nodes for cluster development. Many clusters enjoy the knowledge assets and research infrastructure that are necessary for the development of an innovation-based development strategy, but they differ dramatically in their capacity to mobilize these assets in the pursuit of such a strategy. (Wolfe 2009, 186)

Parrilli, Aranguren, and Larrea $(2010,358)$ reach the same conclusions, pointing out that 'the simple juxtaposition of $R \& D$ centres, labs, universities, venture capitalists may not produce innovation if they do not have effective interaction'. Therefore, sufficiently qualified firms are necessary to sustain the dialogue or feed-back between the user and the provider of services.

The differing roles observed between the sectors related to the knowledgecreation-diffusion (i.e. glazing) versus carriers-of-knowledge (i.e. ceramics) processes are crucial for policymakers. The need to address the ceramic SMEs' internal resources to build $\mathrm{AC}$ and enable them to access the local $\mathrm{TCs}$ to acquire technology is an issue that needs to be addressed in clusters, beyond the generic policies that tacitly reflect a homogeneous way of understanding the cluster. The results presented herein are directly related to the idea of heterogeneity (Nelson and Winter 1982; Nelson 1991) in clusters, i.e., differing knowledge bases which moderate the types of external resources that can be accessed, confirming previous studies (Giuliani 2007). Therefore, policymakers should work at different levels within clusters, not only to distinguish knowledge providers and carriers, but also the differences, i.e., heterogeneity, between the carriers. It is vital to consider the idea of the regionalization of innovation policy (Fritsch and Stephan 2005) and to understand the impact of the different roles that the available research infrastructure has in the 
territory on these sectors and firms. This also implies a careful analysis of how the specific interaction between cluster agents occurs and an understanding of the channels through which the knowledge is diffused. In addition, policymakers should also focus on SMEs and their ability to take advantage of the R\&D infrastructure and to reinforce SMEs' resources to ensure that they can access certain R\&D infrastructures. These results are confirmed by previous studies which suggested the need to support programmes which make it attractive for firms, and in particular specially LMT and SMEs, to hire academically qualified personnel and more generally to upgrade their in-house skills (Lundvall 2002; Muscio 2007). Therefore, internal investments in $\mathrm{AC}$, even in terms of non-R\&D efforts, can improve the access to external flows of knowledge.

Lastly, an important reflection regarding the results needs to be made. First, the literature has pointed out the weak relationship between SMEs and TCs, especially evident in the case of low-tech contexts, as evidenced by our study and others (Parrilli, Aranguren, and Larrea 2010). Our study concludes that the high-intensive industry (i.e. glazing) is the key industry which embraces openness to external sources of knowledge from the ITC. Therefore, what happens when in a cluster of low-tech SMEs there is no high-intensive industry to act as a gatekeeper? What is the role of TCs in this case?

This paper presents several limitations. First, the interactions are based on the firm-to-firm or firm-RTO level, and do not cover personal level interrelationships. Second, the variables addressing social capital (trust, belonging, etc.) are not included in the econometric model. Third, the study is micro-based, i.e., at the firm level, and thus some considerations at the meso-level, such as the role of gatekeepers, are not properly addressed. Lastly, the study is based on a single cluster and the results may not be easily transferred to other types of clusters, especially non-low-tech ones.

For future research, the classification of TCs and their role in different types of clusters should be placed in the cluster research agenda. Moreover, it is necessary to evaluate the role of non-R\&D institutions such as trade associations, fair trade 'contemporary clusters' (Maskell and Malberg 2006) which promote innovation in traditional clusters and other information brokers which are part of the technology infrastructure and influence the local innovation.

\section{Acknowledgements}

We thank the ECO: 2010-17318 Project Innoclusters funded by the Spanish Ministry of Science and Innovation (MICINN) for the period 2011-2013. In addition, Dr. Hervas-Oliver is thankful to Generalitat Valenciana GVA support for visiting London School of Economics (LSE, 2011 BEST programme GVA) during Fall 2011.

\section{Notes}

1. We use indistinctively TCs and IRIs, meaning those support organizations funded by the Government (top-down), different associations (bottom-up) or in a hybrid way in order to provide knowledge-intensive services and value-added activities to firms and mainly to SMEs located in a territory (region, such as Badeb-Württemberg or a national context, Denmark) or cluster (the case of the VR or the Emilia-Romagna, see Mas-Verdú 2007). These institutes are not focused on basic but applied research, which is needed in a day-today basis by SMEs. The services offered by the TCs are not usually covered by 
universities, which are more likely to create new start-ups or act as incubators. For the sake of simplicity, in some papers the term (Belussi, Sammarra, and Sedita 2010) can be found, which include all types of public support organizations, such as TCs, universities, public labs and so forth. Thus, the term technology transfer office (TTOs, see Muscio 2010) refers to universities' transfer offices to commercialize their products (patents and other intellectual property rights, among other activities). Therefore, in this paper, TC or IRI refers to those support organizations that are predominantly created to serve SMEs.

2. www.baden-wuerttemberg.de and www.fraunhofer.de and www.stw.de (accessed on August 2010).

3. This idea is related to the problem of lock-in (Boschma 2005). Agents should enable greater interaction and the distance between firms and TCs should be minimal, although it may be subject to certain limits. Boschma $(2005,62)$ claims that '.. too much and too little proximity (cognitive, organizational, social, institutional and geographical) may be harmful for effective interactive learning and innovation'. Our paper does not cover this aspect.

4. In this study, the concepts of cluster and $I D$ are used indistinctly, although we do recognize differences in both concepts, especially due to the social aspects frequently observed in industrial districts.

5. The flows of knowledge are both traded and un-traded due to the fact that the glazing firms give part of the design process for free as a way of promoting the acquisition of the glaze. Nevertheless, the effect can be the same, regardless of their classification. We believe that, theoretically, this is more correct.

\section{References}

Acs, Z.J., and D.B. y Audretsch. 1990. Innovation and small firms. London: MIT Press.

Albaladejo, M., and H. Romijn. 2000. Determinants of innovation capability in small UK firms: An empirical analysis, WP 00. 13. ECIS. Technische Universiteit Eindhoven, Eindhoven.

Albors-Garrigos, J. 2000. Estudio diagnóstico sobre el sector de maquinaria para la industria cerámica. Técnica Cerámica, Anuario, 8-12.

Albors-Garrigos, J. 2002. Networking and technology transfer in the Spanish ceramic tiles cluster. Its role in the sector competitiveness. The Journal of Technology Transfer 27, no. $3: 263-73$.

Albors-Garrigos, J., and J.L. Hervas-Oliver. 2006. The European tile ceramic industry in the XXI century. Challenges of the present decade. Boletin de la Sociedad Española de Ceramica y Vidreo 45, no. 1: 13-21.

Allen, T.J. 1977. Managing the flow of technology. Cambridge: MIT Press.

Allen, J., D.J. Andrew, and P. Gamlen. 2007. Formal versus informal knowledge networks in R\&D: A case study using social network analysis. R\&D Management 37: 179-96.

Almeida, P., and B. Kogut. 1999. Localization of knowledge and the mobility of engineers in regional networks. Management Science 45: 905-17.

Amit, R., and P. Shoemaker. 1993. Strategic assets and organizational rent. Strategic Management Journal 14: 33-46.

Ang, J.S., R.A. Cole, and J.W. Lin. 2000. Agency costs and ownership structure. Journal of Finance 55: 81-106.

Antonelli, C. 1988. New information technology and industrial change. Norwell, MA: Kluwer.

Antonelli, C., P.P. Patrucco, and F. Quatraro. 2011. Productivity growth and pecuniary knowledge externalities: An empirical analysis of agglomeration economies in European regions. Economic Geography 87: 23-50.

Arbussa, A., and G. Coenders. 2007. Innovation Activities, use of appropriation instruments and absorptive capacity: Evidence from Spanish firms. Research Policy 36, no. 10: $1545-58$. 
Arnold, E. 1998. Developing company technological capabilities. Proceedings of the 4th Atlanta Workshop on the Evaluation of Industrial Modernization, Georgia Institute of Technology, Atlanta, Georgia.

Arnold, E., N. Brown, A. Eriksson, T. Jansson, A. Muscio, J. Nählinder, and N. Zaman. 2007. The role of industrial research institutes in the national innovation system. Stockholm: Vinnova. ISBN: 91-85084-05-0. http://www.vinnova.se/en/Publicationsand-events/Publications/Products/Evaluation-of-the-NUTEK-VINNOVA-programme-in-Complex-Technical-Systems-1997-2001/ (accesed July 2012).

Arundel A., C. Bordoy, and M. Kanerva, 2008. Neglected innovators: How do innovative firms that do not perform $R \& D$ innovate? Results of an analysis of the innobarometer 2007. University of Maastricht: UNU-MERIT.

ASCER. 2005. Estudio económico del sector del Azulejo. Castellon: Publicasa. http// www.ascer.es (accessed August 2009).

Asheim, B.T., and L. Coenen. 2005. Knowledge bases and regional innovation systems: Comparing Nordic clusters. Research Policy 34, no. 8: 1173-90.

Asheim, B.T., and L. Coenen. 2006. Contextualising regional innovation systems in a globalising learning economy. Journal of Technology Transfer 31: 163-73.

Asheim, B.T., Coenen, L., and Svensson-Henning, M. 2003. Nordic SMEs and regional innovation systems - Final Report. Lund: Lund University.

Asheim B.T., and A. Isaksen. 2000. Localised knowledge, interactive learning and innovation: Between regional networks and global corporations. In The networked firm in a global world. Small firms in new environments, eds. E. Vatne and M. Taylor, 163-98. Aldershot: Ashgate.

Aström, T., Eriksson, M.L., Arnold, E. 2008. International comparison of five institute systems. Forsknings-og Innovationsstyrelsen, Copenhagen.

Audretsch, D. 1995. Innovation, growth and survival. International Journal of Industrial Organisation 13: 441-57.

Barge-Gil, A., and A. Modrego-Rico. 2008. Are technology institutes a satisfactory tool for public intervention in the area of technology? A neoclassical and evolutionary evaluation. Environment and Planning C: Government and Policy 26: 808-23.

Becattini, G. 1990. The Marshallian district as a socio-economic notion. In Industrial Districts and Inter-Firm Co-operation in Italy, eds. F. Pyke, G. Becattini, and W. Sengenberger, 37-51. Geneva: International Institute for Labour Studies.

Bellandi, M. 1989. The industrial district in Marshall. In Small firms and industrial districts in Italy, eds. E. Goodman, J. Bamford, and P. Saynor, 136-52. London: Routledge.

Belussi, F., G. Gottardi, and E. Rullani, eds. 2003. The technological evolution of industrial districts. Amsterdam: Kluwer.

Belussi, F., A. Sammarra, and S. Sedita. 2008. Managing long distance and localized learning in the Emilia Romagna life science cluster. European Planning Studies 16, no. 5: $665-92$.

Belussi, F., A. Sammarra, and S. Sedita. 2010. Learning at the boundaries in an "Open Regional Innovation System": A focus on firms' innovation strategies in the Emilia Romagna life science industry. Research Policy 39, no. 6: 710-21.

Belussi, F., and S. Sedita. 2010. Localized and distance learning in industrial districts. In Business networks in clusters and industrial districts: The governance of the global value chain, eds. F. Belussi and A. Sammarra, 24-51. Abingdon, UK: Routledge.

Bennett, R. 1998. Business associations and their potential contribution to the competitiveness of SMEs. Entrepreneurship \& Regional Development 10, no. 3: 243-60.

Benneworth, R., and S. Dawley. 2004. The territorial development of innovation support assets through university-business interactions. In Academia-business links. European policy strategies and lessons learnt, ed. R. Wink, 197-224. Basingstoke, UK: Palgrave Macmillan. 
Benton, L. 1992. The emergence of the industrial district in Spain. In industrial districts and local economic regeneration, eds. F. Pyke, G. Becattini, and W. Sengenberger, 81-128. Geneva: International Institute for Labour Studies.

Bessant, J., and J. Tidd. 2007. Innovation and entrepreneurship. Wiley: Chichester, UK.

Boix, R. 2009. The empirical evidence of industrial districts in Spain. In $A$ handbook of industrial districts, eds. G. Becattini, M. Bellandi, and L. De Propis, 343-59. Cheltenham: Edward Elgar.

Boschma, R. 2005. Proximity and innovation: A critical assessment. Regional Studies 39: 61-74.

Boschma, R.A., and J.G Lambooy. 2002. Knowledge, market structure, and economic coordination: Dynamics of industrial districts. Growth and Change 33, no. 3: 291-311.

Bosco, M.G. 2007. Innovation, R\&D and technology transfer: Policies towards a regional innovation system. The case of Lombardy. European Planning Studies 15, no. 8: $1085-111$.

Bougrain, F., and B. Haudeville. 2002. Innovation, collaboration and SMEs internal research capacities. Research Policy 31: 735-47.

Breschi, S., and F. Lissoni. 2001. Knowledge spillovers and local innovation systems: A critical survey. Industrial and Corporate Change 10, no. 4: 975-1005.

Brouwer, E., and A. Kleinknecht. 1996. Determinants of innovation: A micro econometric analysis of three alternative innovation output indicators. In Determinants of innovation, the message from new indicators, ed. A. Kleinknecht, 99-124. London: Macmillan Press.

Brown, A., T. Van Der Wielle, and K. Loughton. 1998. Smaller enterprises experiences with ISO 9000. International Journal of Quality \& Reliability Management 15, no. 3: 273-85.

Budd, L., and A.K. Hirmis. 2004. Conceptual framework for regional competitiveness. Regional Studies 38, no. 9: 1015-28.

Camagni, R., ed. 1991. Innovation networks: Spatial perspectives. London: Belhaven.

Camagni, R.P. 1992. Development scenarios and policy guidelines for the lagging regions in the 1990. Regional Studies 26: 361-74.

Camisón, C. 2004. Shared, competitive, and comparative advantages: A competence-based view of industrial-district competitiveness. Environment and Planning $\boldsymbol{A}$ 36, no. 12: $2227-56$.

Camuffo, A., and R. Grandinetti. 2011. Italian industrial districts as cognitive systems: Are they still reproducible? Entrepreneurship \& Regional Development 23: 815-52.

Capello, R., and A. Faggian. 2005. Collective learning and relational capital in local innovation processes. Regional Studies 39, no. 1: 75-87.

Casadesus, M., G. Giménez, and I. Heras. 2001. Benefits of ISO 9000 implementation in the Spanish Industry. European Business Review 13, no. 6: 327-36.

Casper, S. 2007. How do technology clusters emerge and become sustainable?: Social network formation and inter-firm mobility within the San Diego biotechnology cluster. Research Policy 36, no. 4: 438-55.

Chaminade, C., and J. Vang. 2008. Globalisation of knowledge production and regional innovation policy: Supporting specialized hubs in the Bangalore software industry. Research Policy 37, no. 10: 1684-96.

Chiarvesio, M., E. di Maria, and S. Micelli. 2004. From local networks of SMES to virtual districts? Evidence from recent trends in Italy. Research Policy 33, no. 10: 1509-28.

Clark, J. 2010. Coordinating a conscious geography: The role of research centers in multiscalar innovation policy and economic development in the US and Canada. The Journal of Technology Transfer 35, no. 5: 460-74.

Cockburn, I., and R. Henderson. 1994. Measuring competence? Exploring firm effects in pharmaceutical research. Strategic Management Journal 15: 63-84.

Coenen, L., J. Moodysson, and B. Asheim. 2004. Nodes, networks and proximity: On knowledge dynamics of the Medicon Valley biotech cluster. European Planning Studies 12, no. 7: 1003-18. 
Cohen, W.M., R. Florida, L. Randazzese, and J. Walsh. 1998. Industry and the academy: Uneasy partners in the cause of technological advance. In Challenges to research universities, ed. R.G. Noll, Chap. 7, 171-200. Washington, DC: The Brookings Institution.

Cohen, W., and D. Levinthal. 1989. Innovation and learning: The two faces of R\&D. Economic Journal 99: 569-96.

Cohen, W., and D. Levinthal. 1990. Absorptive capacity: A new perspective on learning and innovation. Administrative Science Quarterly 35: 128-52.

Coleman, J.C. 1988. Social capital in the creation of human capital. American Journal of Sociology 94: 95-120.

Cooke, P. 2001. Regional innovation systems, clusters, and the knowledge economy. Industrial And Corporate Change 10, no. 4: 945-74.

Cooke, P. 2005. Regionally asymmetric knowledge capabilities and open innovation. Exploring 'globalisation 2', a new model of industry organization. Research Policy 34: $1128-49$.

Cooke, P., C. de Laurentis, F. Tödtling, and M. Trippl. 2007. Regional knowledge economies. Markets, clusters and innovation. Great Britain: Edward Elgar.

Cooke, P., and L. Leydesdorff. 2006. Regional development in the knowledge-based economy: The construction of advantage. Journal of Technology Transfer 31, no. 1: 5-15.

Cooke, P., M. Uranga, and G. Etxebarria. 1997. Regional innovation systems: Institutional and organisational dimensions. Research Policy 26: 475-91.

COTEC. 2003. Informe Cotec: Tecnología e Innovación en España. Spain: Fundación COTEC.

Crevoisier, O. 2004. The innovative milieus approach: Toward a territorialized understanding of the economy? Economic Geography 80: 367-80.

Cross, R., S.P. Borgatti, and A. Parker. 2002. Making invisible work visible: Using social network analysis to support strategic collaboration. California Management Review 44: 25-46.

Dahlander, L., and M. McKelvey. 2005. The occurrence and spatial distribution of collaboration: Biotech firms in Gothenburg, Sweden. Technology Analysis \& Strategic Management 17, no. 4: 409-31.

Dosi, G. 1984. Technical change and industrial transformation. London: Macmillan.

Ervet. 1997. Il Sistema ERVET: la capogrupo e I centri. Bologna: ERVET (mimeo).

Escribano, A., A. Andrea Fosfuri, and J. Tribó. 2009. Managing external knowledge flows: The moderating role of absorptive capacity. Research Policy 38: 96-115.

Freel, M. 2003. Sectoral patterns of small firm innovation, networking and proximity. Research Policy 32: 751-70.

Freel, M. 2005. Patterns of innovation and skills in small firms. Technovation 25: 123-34.

Fritsch, M., and A. Stephan. 2005. Regionalization of innovation policy, introduction to the special issue. Research Policy 34: 1123-7.

Fromhold-Eisebith, M., and G. Eisebith. 2005. How to institutionalize innovative clusters? Comparing explicit top-down and implicit bottom-up approaches. Research Policy 34: $1250-68$.

Galaskiewicz, J. 1985. Social organization of an Urban Grants Economy. New York: Academic Press.

Gallego, J.R. 1997. Cambio tecnológico y transformación de sistemas industriales localizados: El caso de la industria española de pavimentos y revestimientos cerámicos. Tesis Doctoral, Mimeo, Universitat de Valencia.

Gann, D.M., and A.J. Salter. 2000. Innovation in project-based, service-enhanced firms: The construction of complex products and systems. Research Policy 29, no. 7/8: 955-72.

García-Quevedo, J., and F. y Mas-Verdú. 2008. Does only size matter in the use of knowledge intensive services? Small Business Economics 31: 137-46. 
Giner, J.M., and M.J. Santa María. 2002. Territorial systems of small firms in Spain: An analysis of productive and organizational characteristics in industrial districts. Entrepreneurship \& Regional Development 14: 211-28.

Giuliani, E. 2005. Cluster absorptive capacity: Why some clusters forge ahead and others lag behind? European Urban and Regional Studies 12, no. 3: 269-88.

Giuliani, E. 2007. The selective nature of knowledge networks in clusters: Evidence from the wine industry. Journal of Economic Geography 7, no. 2: 139-68.

Giuliani, E., and M. Bell. 2005. The micro-determinants of meso-level learning and innovation: Evidence from a Chilean wine cluster. Research Policy 34, no. 1: 47-68.

Gomes-Casseres, B., J. Hagedoorn, and A.B. Jaffe. 2006. Do alliances promote knowledge flows? Journal Of Financial Economics 80, no. 1: 5-33.

Gómez-Mejía, L.R., M. Larranza-Quintana, and M. Makri. 2003. The determinants of executive compensation in family controlled public corporations. Academy of Management Journal 46: 226-37.

Gorman, G.G., and S. McCarthy. 2006. Business development support and knowledge-based businesses. Journal of Technology Transfer 31: 131-43.

Griliches, Z. 1979. Issues in assessing the contribution of research and development to productivity growth. Bell Journal of Economics 10, no. 1: 92-116.

Guillen, M.F. 1992. Análisis de regresión múltiple. Madrid: Centro de Investigaciones Sociológicas.

Gunasekara, C. 2006. Reframing the role of universities in the development of regional innovation systems. Journal of Technology Transfer 31: 101-13.

Harrison, B. 1991. Industrial districts: Old wine in new bottles? Regional Studies 26: 469-83.

Hassink, R. 1997. Technology transfer infrastructures: Some lessons from experiences in Europe, the US and Japan. European Planning Studies 5, no. 3: 351-70.

Hausman, A. 2005. Innovativeness among small businesses: Theory and propositions for future research. Industrial Marketing Management 34, no. 8: 773-82.

Hervas-Oliver, J.L. 2004. Heterogeneidad Stratégica en un Cluster. Evidencia Empírica de la Identificación de Grupos Estratégicos a Través de la Cadena de Valor y su Impacto en la Performance en el Sector Industrial Cerámico. Unpublished Doctoral Thesis, Polytechnic University of Valencia, Valencia, Spain (in Spanish).

Hervas-Oliver, J.L., and J. Albors-Garrigos. 2007. Do the cluster's resources and capabilities matter? An application of resource-based view in Clusters. Entrepreneurship \& Regional Development 17, no. 2: 113-36.

Hervas-Oliver, J.L., and J. Albors-Garrigos. 2008. Local knowledge domains and the role of MNE affiliates in bridging and complementing a cluster's knowledge. Entrepreneurship \& Regional Development 20, no. 6: 581-98.

Hervas-Oliver, J.L, and J. Albors-Garrigos. 2009. The role of the firm's internal and relational capabilities in clusters: When distance and embeddedness are not enough. Journal of Economic Geography 9, no. 2: 263-83.

Ibrahim, S.E., M.H. Fallah, and R.R. Reilly. 2009. Localized sources of knowledge and the effect of knowledge spillovers. Journal Of Economic Geography 9: 405-31.

Inkpen, A.C., and E.W.K. Tsang. 2005. Social capital, networks, and knowledge transfer. Academy of Management Review 30, no. 1: 146-65.

ITC. 2008. Memoria de actividades, 2008. Instituto de Tecnologia Ceramic, REDIT. Castellon. www.itc.es (accessed summer of 2010).

Izushi, H. 2005. Creation of relational assets through the 'library of equipment' model: An industrial modernization approach of Japan's local technology centres. Entrepreneurship \& Regional Development 17, no. 3: 183-204.

Jaffe, A., M. Trajtenberg, and R. y Henderson. 1993. Geographic localization of knowledge spillovers as evidenced by patent citations. Quarterly Journal of Economics 108, no. 3: 577-98. 
Jenkins, M., and S. Tallman. 2010. The shifting geography of competitive advantage: Clusters, networks and firms with Mark Jenkins. Journal of Economic Geography 10, no. 4: $599-618$.

Jensen, M., B. Johnson, E. Lorenz, and B.A. Lundvall. 2007. Forms of knowledge and modes of innovation. Research Policy 36: 680-93.

Jensen, C., and B. Tragardh. 2004. Narrating the triple helix concept in weak regions: Lessons from Sweden. International Journal of Technology Management 27: 515-28.

Jones, O., A. Macpherson, and R. Thorpe. 2010. Learning in owner-managed small firms: Mediating artefacts and strategic space. Entrepreneurship \& Regional Development 22, nos. 7-8: 649-673.

Justman, M., and M. Teubal. 1995. Technological infrastructure policy (TIP): Creating capabilities and building markets. Research Policy 24: 259-81.

Kalantaridis, C., and J. Pheby. 1999. Processes of innovation among manufacturing SMEs: The experience of Bedfordshire. Entrepreneurship \& Regional Development 11, no. 1: $57-78$.

Kauffeld-Monz, M., and M. Fritsch. 2010. Who are the knowledge brokers in regional systems of innovation? A multi-actor network analysis. Regional Studies, First published on: 5 July 2010 (iFirst).

Kaufmann, A., and F. Tödtling. 2002. How effective is innovation support for SMEs? An analysis of the region of Upper Austria. Technovation 22, no. 3: 147-59.

Kaufmann, A., and P. Wagner. 2005. EU regional policy and the stimulation of innovation: The role of European Regional Development Fund in the objective 1 Region Burgenland. European Planning Studies 13, no. 4: 581-99.

Kesidou, E., M.C.J. Caniëls, and H.A. Romijn. 2009. Local knowledge spillovers and development: An exploration of the software cluster in Uruguay. Industry \& Innovation 16, no. 2: 247-72.

Kirner, E., S. Kinkel, and A. Jaeger. 2009. Innovation paths and the innovation performance of low-technology firms - An empirical analysis of German industry. Research Policy 38, no. 3: 447-58.

Klevorick, A., R. Levin, R. Nelson, and S. Winter. 1995. On the sources of significance of inter-industry differences in technological opportunities. Research Policy 24: $185-205$.

Lagendijk, A. 2000. Learning in non-core region: Toward "intelligent clusters"; addressing business and regional needs. In Knowledge, innovation and economic growth. The theory and practice of learning regions, eds. F. Boekema, K. Morgan, S. Bakkers, and R. Rutten, 165-191. Aldershot: Edward Elgar.

Lambrecht, J., and J. Lievens. 2008. Pruning the family tree: An unexplored path to family business continuity and family harmony. Family Business Review 21, no. 4: 295-313.

Landabaso, M. 2000. Innovation and regional development policy. In Knowledge, innovation and economic growth: The theory and practice of learning regions, eds. F. Boekema, K. Morgan, S. Bakkers, and R. Rutten, 73-94. Cheltenham: Edward Elgar.

Lane, P., P. Koka, and S. Pathak. 2006. The reification of absorptive capacity: A critical review and rejuvenation of the construct. Academy Of Management Review 31, no. 4: 833-63.

Lawson, C. 1999. Towards a competence theory of the region. Cambridge Journal Economics 23: $151-66$.

Lazerson, M.H., and G. Lorenzoni. 1999. The firms that feed industrial districts: A return to the Italian source. Industrial and Corporate Change 8, no. 2: 235-66.

Leitner, K.H. 2005. Managing and reporting intangible assets in TCs. R\&D Management 35, no. 2: $125-36$.

Li, J., and S. Geng. 2011. Industrial clusters, shared resources and firm performance. Entrepreneurship \& Regional Development 24, nos. 5-6: 357-81. 
Li, J.J., L. Poppo, and K. Zhou. 2010. Relational mechanisms, formal contracts, and local knowledge acquisition by international subsidiaries. Strategic Management Journal 31, no. 4: $349-70$.

Lissoni, F. 2001. Knowledge codification and the geography of innovation: The case of Brescia mechanical cluster. Research Policy 30, no. 9: 1479-500.

Love, B., and S. Roper. 1999. The determinants of innovation: R\&D, technology transfer and networking effects. Review of Industrial Organisation 15: 43-64.

Lundvall, B.A., ed. 1992. National system of innovation: Towards a theory of innovation and interactive learning. London: Pinter.

Lundvall, B.-A. 2002. The university in the learning economy, DRUID. http://www.druid.dk/ wp/pdf_files/02-06.pdf (accessed July 2012).

Lundvall, B., and S. Borras. 1999. The globalizing learning economy: Implications for innovation policy. Luxembourg: Office for Official Publications of the European Communities.

Lundvall, B.A., and B. Johnson. 1994. The learning economy. Journal of Industry Studies 1, no. 2 : $23-42$.

Lundvall, B.-A., and P. Nielsen. 1999. Competition and transformation in the learning economy - The Danish case. Revue d'Economie Industrielle 88: 67-90.

Maillat, D. 1989. SMES, innovation and territorial development. Arco, Italy: European Summer Institute of the Regional Science Association.

Maillat, D. 1990. SMEs, innovation and territorial development. In The spatial context of technological development, eds. R. Cappellin and P. Nijkamp, 331-51. Aldershot: Avebury.

Malmberg, A., and P. Maskell, 2005. Localized learning revisited, DRUID Working Paper No. 05-19. Copenhagen: Danish Research Unit for Industrial Dynamics.

Malmberg, A., and D. Power. 2005. (How) Do (Firms in) clusters create knowledge? Special issue on knowledge geographies. Industry and Innovation 12, no. 4: 409-31.

Marklund, G., R. Nilsson, P. Sandgren, J.G. Thorslund, and J. Ulström. 2004. The Swedish national innovation system 1970-2003: A quantitative international benchmarking analysis. Vinnova Analysis VA 2004:1. Stockholm: Vinnova. http://www.vinnova.se/ upload/EPiStorePDF/va-04-01.pdf (accessed July 2012).

Martínez-Gómez, V., A. Baviera Puig, and F. Mas-Verdú. 2009. Innovation policy, services and internationalization: The role of technology centres. The Services industries Journal 1, no. 14: 2-19.

Maskell, P. 2001. Towards knowledge based theory of the geographical cluster. Industrial and Corporate Change 10: 921-43.

Maskell, P., and A. Malmberg. 1999. Localised learning and industrial competitiveness. Cambridge Journal of Economics 23, no. 2: 167-85.

Maskell, P., and A. Malmberg. 2006. Localized learning revisted. Growth and Change, 37, no. 1: $1-18$.

Mas-Verdú, F. 2003. Centros Tecnológicos y Sistemas Regionales de Innovación: Modelos Europeos. Investigaciones Regionales, Otoño, 003: 129-61.

Mas-Verdú, F. 2007. Services and innovation systems: European models of technology centres. Services Business 1: 7-23.

Mas-Verdú, F., A. Baviera-Puig, and V. Martinez-Gomez. 2009. Entrepreneurship policy and targets: The case of a low absorptive capacity region. International Entrepreneurship and Management Journal 5: 243-58.

Mas-Verdú, F., and D. Ribeiro. 2008. Rol de la política industrial en el entrepreneurship: ¿cambia la tendencia? Información Comercial Española 841: 85-96.

McEvily, B., and A. Zaheer. 1999. Bridging ties: A source of firm heterogeneity in competitive capabilities. Strategic Management Journal 20: 1133-56.

Metcalfe, J.S., and I. Miles, eds. 2000. Innovation systems in the service economy: Measurement and case study analysis, Massachusetts, USA: Kluwer Academic. 
Meyer-Stamer, J., C. Maggi, and S. Seibel. 2004. Upgrading the tile industry of Italy, Spain, and Brazil: Insights from cluster and value chain analysis. In Local enterprises in the global economy: Issues of governance and upgrading, ed. H. Schmitz, 174-99. Cheltenham, UK: Edward Elgar.

Meyer-Stamer, J., S. Seibel, and C. Maggi. 2001. Improving upon nature. Report 54/2001, University of Duisburg, Germany.

MIK. 2006. Analisis del Capital Social en el Sector de la Madera y Mueble de Urola Erdia Project Document. Azkoitia: Iraurgi Lantzen.

Miles, I. 2001. Knowledge-intensive business services. Revisited Katholieke Universiteit Leuven, Maklu Antwerpen-Apeldoorn.

Morrison, A. 2008. Gatekeepers of knowledge within industrial districts: Who they are, how they interact. Regional Studies 42, no. 6: 817-35.

Muller, E., and A. Zenker. 2001. Business services as actors of knowledge transformation: The role of KIBS in regional and national innovation systems. Research Policy 30, no. 9: $1501-16$.

Munari, F., A. Malipiero, and M. Sobrero. 2005. Focal firms as technological gatekeepers within industrial districts: Evidence from the packaging machinery industry. Working Paper Number 05-05. Copenhagen: Danish Research Unit for Industrial Dynamics (DRUID).

Muscio, A. 2007. The impact of absorptive capacity on SMES' collaboration. Economics of Innovation and New Technology, 16, no. 8: 653-68.

Muscio, A. 2010. What drives the university use of technology transfer offices? Evidence from Italy. The Journal of Technology Transfer 35, no. 2: 181-202.

Nelson, R. 1991. Why do firms differ and how does it matter? Strategic Management Journal 12, no. 1: 61-74.

Nelson, R., ed. (1993). National innovation systems: A comparative analysis. Oxford: Oxford University Press.

Nelson, R., and S. Winter. 1982. An evolutionary theory of economic change. Cambridge, MA: Harvard University Press.

OECD. 1994. Proposed guideliness for collecting and interpreting technological innovation DATA, the OSLO Manual. OECD, Paris.

OECD. 2001. The Pisa Model. Paris: Organisation for Economic Co-operation and Development.

OECD. 2005. OSLO manual: Guidelines for collecting and interpreting innovation. 3rd ed. Paris: OECD Publications.

Olazaran, M., E. Albizu, and B. Otero. 2009. Technology transfer between technology centres and SMEs: Evidence from the Basque country. European Planning Studies 17:3 345-63.

Parrilli, M.D., M.J. Aranguren, and M. Larrea. 2010. The role of interactive learning to close the "Innovation Gap" in SME-based local economies: A furniture cluster in the Basque country and its key policy implications. European Planning Studies 18, no. 3: 351-70.

Pavitt, K. 1984. Sectorial patterns Of technical change: Towards a taxonomy and a theory. Research Policy 13: 343-73.

Pietrobelli, C., R. Rabellott, and E. Giuliani. 2005. Upgrading in global value chains: Lessons from Latin America clusters. World Development 33, no. 4: 549-73.

Pisano, G.P., M.V. Russo, and D.J. Teece. 1988. Joint ventures and collaborative arrangements in the telecommunications equipment industry. In International collaborative ventures in U.S. manufacturing, ed. D.C. Mowery, 23-70. Cambridge: Ballinger.

Piva, M., and M. Vivarelli. 2002. The skill-bias: Comparative evidence and econometric test. International Review of Applied Economics 16, no. 3: 347-57.

Porter, M.E. 1990. The competitive advantage of nations. New York: The Free Press. 
Ranaweera, C., and J. Prabhu. 2003. The influence of satisfaction, trust and switching barriers on customer retention in a continuous purchasing setting. International Journal of Service Industry Management 14, no. 4: 374-95.

Raymond, L., and J. St-Pierre. 2009. R\&D as a determinant of innovation in manufacturing SMEs: An attempt at empirical clarification. Technovation 29, no. 9: 588-95.

Redit. 2009. Informe anual. Valencia: REDIT. http://www.redit.es/media/memorias/ Informe_anual_REDIT_2009.pdf (accessed July 2012).

Robertson, P.L., E. Pol, and P. Carroll. 2003. Receptive capacity of established industries as a limiting factor in the economy's rate of innovation. Industry and Innovation 10: 457-74.

Robinson, D., A. Rip, and V. Mangematin. 2007. Technological agglomeration and the emergence of clusters and networks in nanotechnology. Research Policy 36, no. 6: $871-9$.

Rocha, F. 1999. Inter-firm technological cooperation: Effects of absorptive capacity, firm-size and specialization. Economics of Innovation and New Technology 8: 253-71.

Rolfo, S., and G. Calabrese. 2003. Traditional SMEs and innovation: The role of the industrial policy in Italy. Entrepreneurship \& Regional Development 15, no. 3: 253-71.

Ronde, P., and C. Hussler. 2005. Innovation in regions: What does really matter? Research Policy 34: 1150-72.

Roper, S., and J. Love. 2002. Innovation and export performance: Evidence the UK and German manufacturing plants. Research Policy 31, no. 7: 1087-102.

Rosenberg, N. 1976. Perspectives on technology. New York: Cambridge University Press.

Russo, M. 2004. The ceramic industrial district facing the challenge from China, University of Modena and Reggio Emilia. www.cei.unimore.it (accessed 30 August 2004).

Rutten, R. 2000. Innovation in regional supplier networks: The case of KIC. In Knowledge, innovation and economic growth. The theory and practice of learning regions, eds. K. Boekema, K. Morgan, S. Bakkers, and R. Rutten, 217-41. Aldershot: Edward Elgar.

Santamaría, L., M. Nieto, and A. Barge-Gil. 2009. Beyond formal R\&D: Taking advantage of other sources of innovation in low- and medium-technology industries. Research Policy 38, no. 3: 507-17.

Saxenian, A. 1994. Regional Advantage: Culture and Competition in Silicon Valley and Route 128. Cambridge, MA: Harvard University Press.

Scitovsky, T. 1954. Two concepts of external economies. Journal of Political Economy 62: $143-51$.

Scott, A.J. 1988. Flexible production systems and regional development - The rise of new industrial spaces in North America and Western Europe. International Journal of Urban and Regional Research 12, no. 2: 171-86.

Scott, A.J. 2004. A perspective of economic geography. Journal of Economic Geography 4 , no. 5: 479-99.

Segarra-Blasco, A., and J.M. Arauzo-Carod. 2008. Sources of innovation and industryuniversity interaction: Evidence from Spanish firms. Research Policy 37: 1283-95.

Siu, W.-S., W. Fang, and T. Lin. 2004. Strategic marketing practices and the performance of Chinese small and medium-sized enterprises (SMEs) in Taiwan. Entrepreneurship \& Regional Development 16, no. 2: 161-78.

Smith, K. 2000. Innovation as a systemic phenomenon: Rethinking the role of policy. Enterprise and Innovation Management Studies 1, no. 1: 73-102.

Sölvell, Ö., G. Lindqvist, and C. Ketels. 2003. The cluster initiative greenbook. Stockholm. http://www.europe-innova.eu/c/document_library/get_file?folderId = 148900\&name = DLFE-6119.pdf (accessed July 2012).

Souitaris, V. 2002. Technological trajectories as moderators of firm level determinants of innovation. Research Policy 31: 877-98.

Storper, M. 1995. The resurgence of regional economies ten years later: The region as a nexus of untraded interdependencies. European Urban and Regional Studies 2: 191-221. 
Tann, J., A.E. Platts, and J. Stein. 2002. The roles of independent TCs in the U.K. technology transfer mechanisms to SMEs. Technology Analysis \& Strategic Management 14, no. 2: $241-9$.

Terziovski, M. 2010. Innovation practice and its performance implications in small and medium enterprises (SMEs) in the manufacturing sector: A resource-based view. The Journal of Strategic Management Journal 31, no. 8: 892-902.

Tidd, J. 2000. Measuring strategic competencies: Technological, market and organisational indicators of innovation. London: Imperial College Press.

Tödtling, F., and M. Trippl. 2005. One-size-fits-all? Towards a differentiated regional policy approach. Research Policy 34: 1203-19.

Tomás-Carpi, J.A., J., Banyuls, E., Cano, J.L., Contreras, J.R., Gallego, J.V., Picher, J. Such, and M. Torrejón. 1999. Dinámica industrial e innovación en la Comunidad Valenciana, Generalitat Valenciana (Conselleria d'Ocupació, Indústria y Comerç), Valencia: IMPIVA.

Trippl, M., F. Tödtling, and L. Lengauer. 2009. Knowledge sourcing beyond buzz and pipelines: Evidence from the Vienna software sector. Economic Geography 85, no. 4: $443-62$.

Tura, T., and V. Harmaakorpi. 2005. Social capital in building regional innovative capability. Regional Studies 39: 1111-26.

Uzzi, B. 1996. The sources and consequences of embeddedness for the ECONOMIC performance of organizations: The network effect. American Sociological Review 61, no. 4: 67498 .

Uzzi, B. 1997. Social structure and competition in interfirm networks: The paradox of embeddedness. Administrative Science Quarterly 42: 35-67.

Valdaliso, J., A. Elola, M. Aranguren, and S. Lopez. 2011. Social capital, internationalization and absorptive capacity: The electronics and ICT cluster of the Basque country. Entrepreneurship \& Regional Development 23, nos. 9-10: 707-33.

Vega-Jurado, J., A. Gutierrez-Gracia, I. Fernández-de-Lucio, and L. Manjarrés-Henríquez. 2008. The effect of external and internal factors on firms' product innovation. Research Policy 37: 616-32.

Velluzzi, N.D. 2010. Community colleges, clusters, and competition: A case from Washington wine country. Regional Studies 44, no. 2: 201-14.

Veugelers, R., and B. Cassiman. 2005. R\&D cooperation between firms and universities. Some empirical evidence from Belgian manufacturing. International Journal of Industrial Organization 23: 355-79.

Vickers, I., and D. North. 2000. Regional technology initiatives: Some insights from the English regions. European Planning Studies 8, no. 3: 301-18.

Vloeberghs, D., and J. Bellens. 1996. Implementing the ISO 9000 standards in Belgium. Quality Progress 29, no. 6: 43-8.

Von Hippel, E. 1988. The sources of innovation. New York: Oxford University Press.

Wenger, E., R.A. McDermott, and W. Snyder. 2002. Cultivating communities of practice: A guide to managing knowledge. Boston: Harvard Business School Press.

Wolfe, D.A. 2009. Introduction: Embedded clusters in the global economy. European Planning Studies 17, no. 2: 179-87.

Wolfe, D.A., and M.S. Gertler. 2004. Clusters from the inside and out: Local dynamics and global linkages. Urban Studies 41, no. 5/6: 1071-93.

Ybarra, J.A. 1991. Industrial districts and the Valencian community. Discussion Papers DP/ 44, New Industrial Organisation Programme, International Labour Organization, Geneva. 